\title{
THE GREAT LAKES HYDROGRAPHY DATASET: CONSISTENT, BINATIONAL WATERSHEDS FOR THE LAURENTIAN GREAT LAKES BASIN ${ }^{1}$
}

\author{
Danielle K. Forsyth, Catherine M. Riseng, Kevin E. Wehrly, Lacey A. Mason, John Gaiot, Tom Hollenhorst, \\ Craig M. Johnston, Conrad Wyrzykowski, Gust Annis, Chris Castiglione, Kent Todd, Mike Robertson, Dana M. \\ Infante, Lizhu Wang, James E. McKenna, and Gary Whelan ${ }^{2}$
}

\begin{abstract}
Ecosystem-based management of the Laurentian Great Lakes, which spans both the United States and Canada, is hampered by the lack of consistent binational watersheds for the entire Basin. Using comparable data sources and consistent methods, we developed spatially equivalent watershed boundaries for the binational extent of the Basin to create the Great Lakes Hydrography Dataset (GLHD). The GLHD consists of 5,589 watersheds for the entire Basin, covering a total area of approximately $547,967 \mathrm{~km}^{2}$, or about twice the $247,003 \mathrm{~km}^{2}$ surface water area of the Great Lakes. The GLHD improves upon existing watershed efforts by delineating watersheds for the entire Basin using consistent methods; enhancing the precision of watershed delineation using recently developed flow direction grids that have been hydrologically enforced and vetted by provincial and federal water resource agencies; and increasing the accuracy of watershed boundaries by enforcing embayments, delineating watersheds on islands, and delineating watersheds for all tributaries draining to connecting channels. In addition, the GLHD is packaged in a publically available geodatabase that includes synthetic stream networks, reach catchments, watershed boundaries, a broad set of attribute data for each tributary, and metadata documenting methodology. The GLHD provides a common set of watersheds and associated hydrography data for the Basin that will enhance binational efforts to protect and restore the Great Lakes.
\end{abstract}

(KEY TERMS: watersheds; Laurentian Great Lakes; Geographic Information System (GIS); surface water hydrology.)

Forsyth, Danielle K., Catherine M. Riseng, Kevin E. Wehrly, Lacey A. Mason, John Gaiot, Tom Hollenhorst, Craig M. Johnston, Conrad Wyrzykowski, Gust Annis, Chris Castiglione, Kent Todd, Mike Robertson, Dana M. Infante, Lizhu Wang, James E. McKenna, and Gary Whelan, 2016. The Great Lakes Hydrography Dataset: Consistent, Binational Watersheds for the Laurentian Great Lakes Basin. Journal of the American Water Resources Association (JAWRA) 52(5):1068-1088. DOI: 10.1111/1752-1688.12435

\footnotetext{
${ }^{1}$ Paper No. JAWRA-15-0052-P of the Journal of the American Water Resources Association (JAWRA). Received April 23, 2015; accepted April 19, 2016. (C) 2016 American Water Resources Association. Discussions are open until six months from issue publication.

${ }^{2}$ Resource Analyst (Forsyth) and Fisheries Research Biologist (Wehrly), Institute for Fisheries Research, Michigan Department of Natural Resources and University of Michigan, 400 North Ingalls Building, NIB G250, Ann Arbor, Michigan 48109; Assistant Research Scientist (Riseng) and GIS Analyst (Mason), School of Natural Resources and Environment, University of Michigan, Ann Arbor, Michigan 48109; Water Resources Information Project Data Analyst (Gaiot), Project Manager (Todd), and Imagery Project Manager (Robertson), Ontario Ministry of Natural Resources and Forestry, Peterborough, Ontario, Canada K9J8M5; Ecologist (Hollenhorst), Mid-Continent Ecology Division, U.S. Environmental Protection Agency, Duluth, Minnesota 55804; Physical Scientist GIS (Johnston), New England Water Science Center, U.S. Geological Survey, Pembroke, New Hampshire 03275; Retired Geomatics Data Specialist (Wyrzykowski), Agriculture and Agri-Food Canada, Winnipeg, Manitoba, Canada R3C3G7; Great Lakes Research Specialist (Annis), The Nature Conservancy of Michigan, Lansing, Michigan 48906; Fish and Wildlife Biologist (Castiglione), Lower Great Lakes Fish and Wildlife Conservation Office, U.S. Fish and Wildlife Service, Basom, New York 14013; Associate Professor (Infante), Department of Fisheries and Wildlife, Michigan State University, East Lansing, Michigan 48824; Biological Scientist (Wang), Great Lakes Office, International Joint Commission, Detroit, Michigan 48232; Research Ecologist (McKenna), Great Lakes Science Center, U.S. Geological Survey, Cortland, New York 13045; and Research Program Manager (Whelan), Fisheries Division, Michigan Department of Natural Resources, Lansing, Michigan 48909 (E-Mail/Forsyth: ForsythD1@Michigan.gov).
} 
The Great Lakes Hydrography Dataset: Consistent, Binational Watersheds for the Laurentian Great Lakes Basin

\section{INTRODUCTION}

Tributaries of the Laurentian Great Lakes have been increasingly recognized as key drivers of ecological condition in both nearshore (Danz et al., 2007; Yurista et al., 2011, 2012; Howell et al., 2012; Kelly and Yurista, 2013) and offshore waters (Riseng et al., 2010; Wehrly et al., 2012; Allan et al., 2013). For example, nutrient loads from the Maumee River influence water quality and toxic algae blooms in the western basin of Lake Erie (Michalak et al., 2013), and sediment loads from the Muskegon River increase plankton production in offshore waters of Lake Michigan (Johengen et al., 2008). Tributary inputs of nutrients, sediment, and other chemicals to the Great Lakes originate from land-based sources and are largely influenced by human activities in the watershed (USEPA, 1996; Michalak et al., 2013). Therefore, protecting water quality and habitat in the Great Lakes is dependent upon managing tributaries and their watersheds (Great Lakes Water Quality Agreement, 2012; U.S. Environmental Protection Agency and Environment Canada, 2009). However, watershed management across the Great Lakes Basin, (hereafter "Basin") is challenging because tributaries span county, state, provincial, and international units of government and standardized, up-to-date, and widely available datasets, including watershed boundaries, are lacking (IJC, 2009; Wang et al., 2015; Wehrly et al., 2012). Consequently, there is a need to develop standardized watershed boundaries for the entire Basin.

Standardized watershed boundaries for Great Lakes tributaries have several benefits, including the development of more accurate streamflow and loading models that would be consistent across the United States (U.S.) and Canada. Such information could be used to assess nutrient loadings and identify priority watersheds for load reductions to meet nutrient targets outlined in the Great Lakes Water Quality Agreement (2012). Standardized binational watershed boundaries would also provide a consistent framework for assessing and comparing the State of the Lakes Ecosystem Conference (Environment Canada and the U.S. Environmental Protection Agency, 2014) indicators across the Great Lakes (Danz et al., 2007). Additionally, standardized watershed boundaries would also benefit the Council of Great Lakes Governor's Blue Accounting project (Seelbach et al., 2014) by providing consistent units to track and compare watershed conditions across political boundaries. Finally, standardized watershed boundaries for the entire Basin would provide a framework to create Basin wide and lake wide management plans, prioritize locations for funding and management actions, and conduct research for science-based decision making (Wang et al., 2015).

At the time this manuscript was written, the authors were aware of three efforts that had created or were creating binational watershed boundaries in the Basin: the Canada-U.S. Transboundary Hydrographic Data Harmonization (Laitta, 2010), the Hydrological data and maps based on SHuttle Elevation Derivatives at multiple Scales (HydroSHEDS) project (Lehner, 2006), and the Great Lakes Environmental Indicators (GLEI) II Watersheds (Hollenhorst et al., 2007). We identified a need to create consistent binational watershed boundaries because these existing watershed datasets either were not delineated using consistent methods across the entire Basin (Laitta, 2010), were too coarse for modeling and assessment (Lehner, 2006), or were created prior to the development of vetted hydrologically enforced flow direction grids for the entire Basin (Hollenhorst et al., 2007; Tom Hollenhorst, USEPA, 23 July, 2012, personal communication). It is important to note, however, our work creating new watershed boundaries benefitted from hydrography and processing methods developed in previous watershed delineation efforts (Hollenhorst et al., 2007; Laitta, 2010; U.S. Geological Survey et al., 2013).

The Great Lakes Hydrography Dataset (GLHD) is comprised of nested stream networks, reach catchments, and new, consistent watershed boundaries for the entire Great Lakes and upper St. Lawrence River up to the boundary between the Provinces of Ontario and Quebec. The GLHD improves upon these existing watershed efforts by delineating watersheds for the entire Basin using consistent methods; enhancing the precision of watershed delineation using recently developed flow direction grids that have been hydrologically enforced and vetted by provincial and federal water resource agencies; and increasing the accuracy of watershed boundaries by enforcing embayments, delineating watersheds on islands, and delineating watersheds for all tributaries draining to connecting channels. This work was part of a larger effort known as the Great Lakes Aquatic Habitat Framework project or GLAHF (Wang et al., 2015). GLAHF is a geospatial database and classification framework designed to share, track, and integrate aquatic biological and habitat data. Similarly, the GLHD provides a consistent framework for summarizing landscape characteristics and stream attributes, and modeling tributary flow and loading across Canada and the U.S. Throughout the development of the GLHD, input was obtained from a binational advisory team of experts in hydrology, assessment, Geographic Information Systems (GIS), and resource management with the goal of creating a binational watershed layer that could be useful to a variety of stakeholders in the Great Lakes 
(Appendix 1). The objectives of this manuscript were to: (1) describe the data sources and methods used to develop and validate the binational, Basin wide GLHD watersheds; (2) compare the GLHD watersheds to existing watershed datasets; (3) summarize key landscape variables across the Basin using the GLHD watersheds; and (4) provide information about public availability of the GLHD.

\section{METHODS}

Our approach was to delineate watersheds for the entire Basin (Figure 1) using the Arc Hydro data model (Maidment, 2002) based on methods modified from Hollenhorst et al. (2007) and Merwade (2012). Table 1 shows Canadian and U.S. hydrography datasets that were evaluated for use in delineating watersheds. These datasets were created at dates ranging from 2006 to 2013 and represented a range of resolutions. Based on input from our advisory team, the Ontario Integrated Hydrology Data (OIHD) v1.0 (OMNR, 2012) was selected for Canada and the National Hydrography Dataset Plus (NHDPlus) v2 (McKay et al., 2012) was selected for the U.S. These hydrography datasets were chosen because they were both released in 2012 and included stream-enforced flow direction grids at $30 \mathrm{~m}$ resolution. The other available data sources either did not provide flow direction grids, provided flow direction grids but at a resolution that was too coarse, or had been retired for the Basin. Although it is possible to create flow direction grids using other hydrography layers such as the high resolution 1:24,000 National Hydrography Dataset (NHD), the existing flow direction grids in the OHIDv1.0 and the NHDPlus v2 were vetted by U.S. Environmental Protection Agency (USEPA), U.S. Geological Survey (USGS), and Ontario Ministry of Natural Resources and Forestry (OMNRF) and are widely accepted and used datasets (Brakebill et al., 2011; Greene et al., 2014). Thus, we felt these datasets represented the most comparable data between Canada and the U.S. that would result in the most accurate delineation of watershed boundaries across the Basin.

One goal of this project was to develop watershed boundaries for Great Lakes tributaries on both the mainland and on islands. OIHDv1.0 flow direction grids on the Canadian side of the Basin provided coverage for both the Canadian mainland and islands. However, for islands on the U.S. side, flow direction grids in the NHDPlus v2 were only available for Drummond Island in Lake Huron and Grand Island in Lake Superior (McKay et al., 2012). For the remainder of the islands on the U.S. side of the Basin, additional

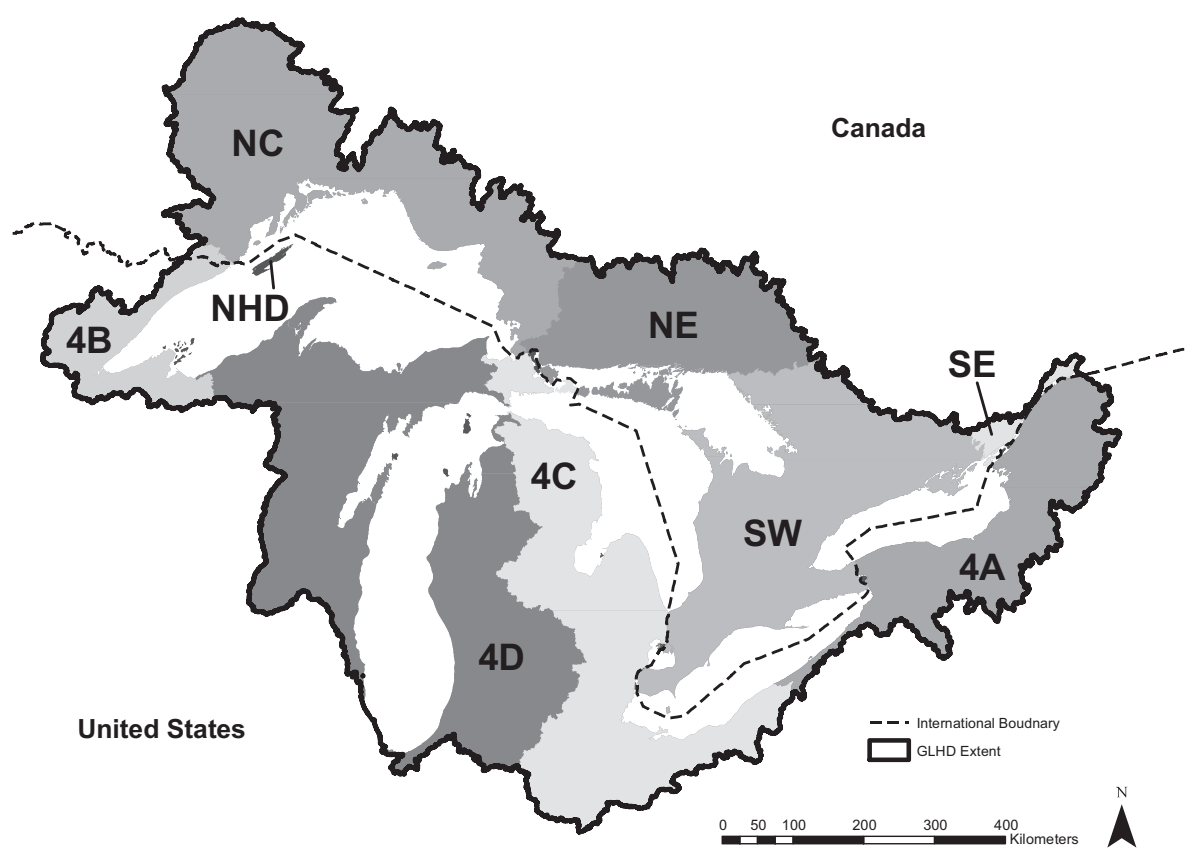

FIGURE 1. The Great Lakes Hydrography Dataset (GLHD) Coverage Extent and Input Data Extents. Watershed coverage of the Laurentian Basin is indicated with a black line; the international boundary is indicated in a black dashed line; the shaded areas illustrate the U.S. (National Hydrography Dataset Plus v2 (NHDPlus v2): 4A, 4B, 4C, and 4D) and Canadian (Ontario Integrated Hydrology Data v1.0 (OIHDv1.0), North Central (NC), North East (NE), South West (SW), and South East (SE)) processing units used for delineating watersheds. NHD (National Hydrography Dataset) indicates data was not available for islands in the NHDPlus v2 and the delineation sources were the 1:24,000 NHD and the $30 \mathrm{~m}$ National Elevation Dataset (NED) Digital Elevation Model (DEM). 
TABLE 1. Resolution, Coverage, and Update Year for All of the Data Sources Considered for Watershed Delineation. The resolution of the stream network was only included for the network inside the Basin. In some cases, such as the Ontario Hydro Network (OHN) and the National Hydro Network (NHN), there are other resolutions (in these cases 1:50,000) outside of the area covered by the GLHD.

\begin{tabular}{|c|c|c|c|c|c|c|}
\hline Name & $\begin{array}{c}\text { Stream } \\
\text { Resolution }\end{array}$ & $\begin{array}{c}\text { Flow } \\
\text { Direction } \\
\text { Grid } \\
\text { Resolution }\end{array}$ & Coverage & $\begin{array}{l}\text { Last Publically } \\
\text { Available Update }\end{array}$ & Source & $\begin{array}{l}\text { Download } \\
\text { Link }\end{array}$ \\
\hline $\begin{array}{l}\text { Arc Hydro } \\
\text { Quaternary } \\
\text { Watershed } \\
\text { Sessions }\end{array}$ & $\begin{array}{l}1: 20,000 \text { and } \\
1: 10,000\end{array}$ & $\begin{array}{l}10 \mathrm{~m} \text { in } \\
\text { Southern } \\
\text { Ontario; } \\
20 \mathrm{~m} \text { in } \\
\text { Northern } \\
\text { Ontario }\end{array}$ & Ontario & 2009 & OMNRF & $\begin{array}{l}\text { https://www.javacoeapp.lrc. } \\
\text { gov.on.ca/geonetwork/srv/ } \\
\text { en/main.home }\end{array}$ \\
\hline HydroSHEDS & $\begin{array}{l}\text { 1:1,000,000- } \\
1: 1,300,000 \text {; also } \\
\text { includes water } \\
\text { bodies delineated } \\
\text { from } 30 \mathrm{~m} \\
\text { elevation data }\end{array}$ & $\begin{array}{l}90 \text { m at best } \\
\text { near the } \\
\text { equator }\end{array}$ & Global & 2006 & WWF & $\begin{array}{l}\text { http://hydrosheds.cr.usgs. } \\
\text { gov/dataavail.php }\end{array}$ \\
\hline $\mathrm{NHN}^{1}$ & $\begin{array}{l}1: 20,000 \text { and } \\
1: 10,000\end{array}$ & $\mathrm{n} / \mathrm{a}$ & Canada & 2008 & NRCan & $\begin{array}{l}\text { http://www.nrcan.gc.ca/ } \\
\text { earth-sciences/geography/ } \\
\text { topographic-information/ } \\
\text { free-data-geogratis/11042 }\end{array}$ \\
\hline $\begin{array}{l}\text { NHD High } \\
\text { Resolution }^{1}\end{array}$ & $1: 24,000$ & $\mathrm{n} / \mathrm{a}$ & $\begin{array}{l}\text { United } \\
\text { States }\end{array}$ & $\begin{array}{l}\text { Updates } \\
\text { ongoing }\end{array}$ & USGS & http://nhd.usgs.gov/data.htm \\
\hline NHDPlus v2 & $1: 100,000$ & $30 \mathrm{~m}$ & $\begin{array}{l}\text { United } \\
\text { States }\end{array}$ & 2012 & $\begin{array}{l}\text { Horizon } \\
\text { System Corps }\end{array}$ & $\begin{array}{l}\text { http://www.horizon- } \\
\text { systems.com/NHDPlus/ } \\
\text { NHDPlus v2_data.php }\end{array}$ \\
\hline OIHDv1.0 & $\begin{array}{l}1: 20,000 \text { and } \\
1: 10,000\end{array}$ & $30 \mathrm{~m}$ & Ontario & $\begin{array}{l}\text { Updates } \\
\text { ongoing }\end{array}$ & OMNRF & $\begin{array}{l}\text { https://www.javacoeapp.lrc. } \\
\text { gov.on.ca/geonetwork/srv/ } \\
\text { en/main.home }\end{array}$ \\
\hline $\mathrm{OHN}$ & $\begin{array}{l}1: 20,000 \text { and } \\
1: 10,000\end{array}$ & $\mathrm{n} / \mathrm{a}$ & Ontario & $\begin{array}{l}\text { Updates } \\
\text { ongoing }\end{array}$ & OMNRF & $\begin{array}{l}\text { https://www.javacoeapp. } \\
\text { lrc.gov.on.ca/geonetwork/ } \\
\text { srv/en/main.home }\end{array}$ \\
\hline $\begin{array}{l}\text { Provincial } \\
\text { Enhanced } \\
\text { Flow Direction } \\
\text { Grid v2.0 }\end{array}$ & $\begin{array}{l}1: 20,000 \text { and } \\
1: 10,000\end{array}$ & $\begin{array}{l}10 \mathrm{~m} \text { in } \\
\text { Southern } \\
\text { Ontario; } 20 \mathrm{~m} \\
\text { in Northern } \\
\text { Ontario }\end{array}$ & Ontario & 2008 & OMNRF & $\begin{array}{l}\text { https://www.javacoeapp. } \\
\text { lrc.gov.on.ca/geonetwork/ } \\
\text { srv/en/main.home }\end{array}$ \\
\hline
\end{tabular}

Notes: HydroSHEDS, Shuttle Elevation Derivatives at multiple scales; NHD, National Hydrography Dataset; NRCan, Natural Resources Canada; OIHDv1.0, Ontario Integrated Hydrology Data v1.0; OMNRF, Ontario Ministry of Natural Resources and Forestry; USGS, U.S. Geological Survey; WWF, World Wildlife Fund

${ }^{1}$ Note that once the NHN/NHD stream networks are harmonized by the Canada-U.S. Transboundary Hydrographic Data Harmonization effort, the harmonized networks will then be incorporated back into the original NHD and NHN datasets, so there is no separate entry for the NHN/NHD harmonized layer in this table.

stream-enforced flow direction grids were created by lowering values for grid cells in the 1 arc second ( $\sim 30 \mathrm{~m})$ 2009-2011 (NED) elevation grids that coincided with river reaches in the high resolution 1:24,000 National Hydrography Dataset NHD drainage network. This process ensures flow continuity and flow direction along the course of a drainage network (Hollenhorst et al., 2007). The 1:24,000 NHD was selected because it provided the most comprehensive stream network data for islands in the U.S. waters of the Great Lakes. For the Basin, 247 of 29,100 islands were large enough to have drainage lines depicted on the 1:24,000 NHD network (U.S. islands) and on the OIHDv1.0 network (Canadian islands) and were candidates for watershed delineation.

Before implementing the Arc Hydro data model, input flow direction grids were modified in five ways. First, areas outside of the Basin were removed from the flow direction grids. Second, OIHDv1.0 flow direction grids were clipped at the shoreline using a shoreline polygon derived from the Ontario Hydro Network (OHN) water-body layer. Third, flow direction grids for the NHDPlus v2 were clipped at the shoreline in connecting channels, including the St. Mary's River, St. Clair and Detroit Rivers System (SCDRS), Niagara River, and the St. Lawrence River using water features from the NHD 1:24,000. Fourth, 
flow direction grids for islands were clipped using shorelines created from island features in the OHN, National Hydro Network (NHN), and the 1:24,000 NHD, with additional island boundaries added from aerial imagery that were visible at the 1:24,000 scale. Finally, flow direction grids were modified at the shoreline to include the Bay of Quinte from the OHN and 35 bays found in the USEPA Great Lakes Basin bays dataset (USEPA, 1992). Adding these bays resulted in a more accurate depiction of where GLHD watersheds meet the shoreline, as illustrated in Lake Superior's St. Louis River Estuary in Figure 2. Table 2 lists and describes all of the datasets used to modify the input flow direction grids.

Arc Hydro was used to develop watershed boundaries in a step-wise fashion using a suite of tools. Flow direction grids were used to create flow accumulation grids, which provided a measure of potential upstream accumulation along a flow network (Maidment, 2002). From the flow accumulation grids, confluence to confluence drainage lines were created, then reach catchments, and finally aggregated reach catchments and downstream outlet points where major tributaries discharge to the Great Lakes. The stream drainage lines were created using an upstream threshold area of $3,00030 \mathrm{~m} \times 30 \mathrm{~m}$ grid cells to initiate delineation of a stream-reach (equivalent to $2.7 \mathrm{~km}^{2}$ ), following recommendations in Hollenhorst et al. (2007). Tributary watersheds were delineated by OIHDv1.0 and NHDPlus v2 hydrologic processing units, and by basin for most U.S. islands (Figure 1) and subsequently combined. In a secondary GIS processing step, watershed boundaries were delineated for interfluves. Interfluves are areas along the Great Lakes shoreline that are drained by multiple, small coastal streams and are not included in a major tributary watershed (Gilliam et al., 1997). Attributes and sources for data used in watershed delineation are shown in Table 2.

Following initial Arc Hydro processing, watershed boundaries were edited in several ways. First, small isolated and erratic watersheds were combined with adjacent interfluve watersheds. Second, local sink watersheds were combined topographically with bordering watersheds so the entire area of the Basin would drain to watershed outlet points. Finally, overlaps and gaps were removed in the boundary waters between Ontario and Minnesota, the only locations where the modified OIHDv1.0 and NHDPlus v2 flow direction grids coincided. Flow direction grids were not altered for large anthropogenic modifications such as shipping channels; all such diversions were maintained as represented in the original flow direction grids. Additional information on how watershed boundaries were edited can be found in the GLHD metadata.
The final edited watershed boundaries and outlet point layers were imported into a geodatabase, the GLHDv1.0. Along with the final layers, some "intermediate" layers such as drainage lines and reach catchments created during Arc Hydro watershed delineation, were included in the geodatabase. These intermediate layers can be used in future watershed studies and provide reference material for users interested in replicating the GLHD watershed delineation methods. To facilitate use of the GLHD with existing hydrography data, the geodatabase also includes stream networks from the OIHDv1.0 and NHDPlus $\mathrm{v} 2$, and reach catchments from the NHDPlus v2. These stream networks and reach catchments were modified to account for changes made in shorelines, connecting channels, and bays associated with the GLHD watershed boundaries. Attributes such as stream names and stream orders (Appendix 2) for the downstream most drainage line were linked from the original NHDPlus v2, OIHD v1.0, and NHD stream networks to the GLHD watersheds. Names for U.S. streams were taken from the NHDPlus v2 and NHD. Names of Canadian streams were taken from the Geographic Named Extent (GEL) layer and NHN layers because stream names were not available in the OHIDv1.0. Unique identifiers were assigned to each watershed in the Basin starting with the watershed in the Ontario and Minnesota boundary waters and continuing counterclockwise across the Basin in sequential order (Hollenhorst et al., 2007). Island watersheds were also assigned unique identifiers using the same counterclockwise sequential numbering method beginning with the northwestern-most island, Isle Royale, in Lake Superior. The geodatabase includes metadata describing data sources, methods, and attribute tables associated with each layer.

As the GLHD was developed as part of the larger GLAHF project, we used the GLHD watersheds to summarize a subset of Canadian and U.S. datasets that had been cross-walked by the GLAHF project (Wang et al., 2015). The GLAHF Basin wide datasets included land use/land cover, roads, and population density and are listed in Table 3. Land use/land cover data (Appendix 3) were summarized by percent area for each watershed. Road density for each watershed was calculated by dividing the length of all roads within a watershed by watershed area. Population density was calculated by first creating an area-weighted population count estimate for each watershed, and then dividing that value by the watershed area. GIS procedures were carried out using ArcGIS 10 (Esri, 2011) and Python 2.6 (Van Rossum and Drake, 2009). All statistics were calculated using $\mathrm{R}$ Statistical Software ( $\mathrm{R}$ Core Team, 2014). 

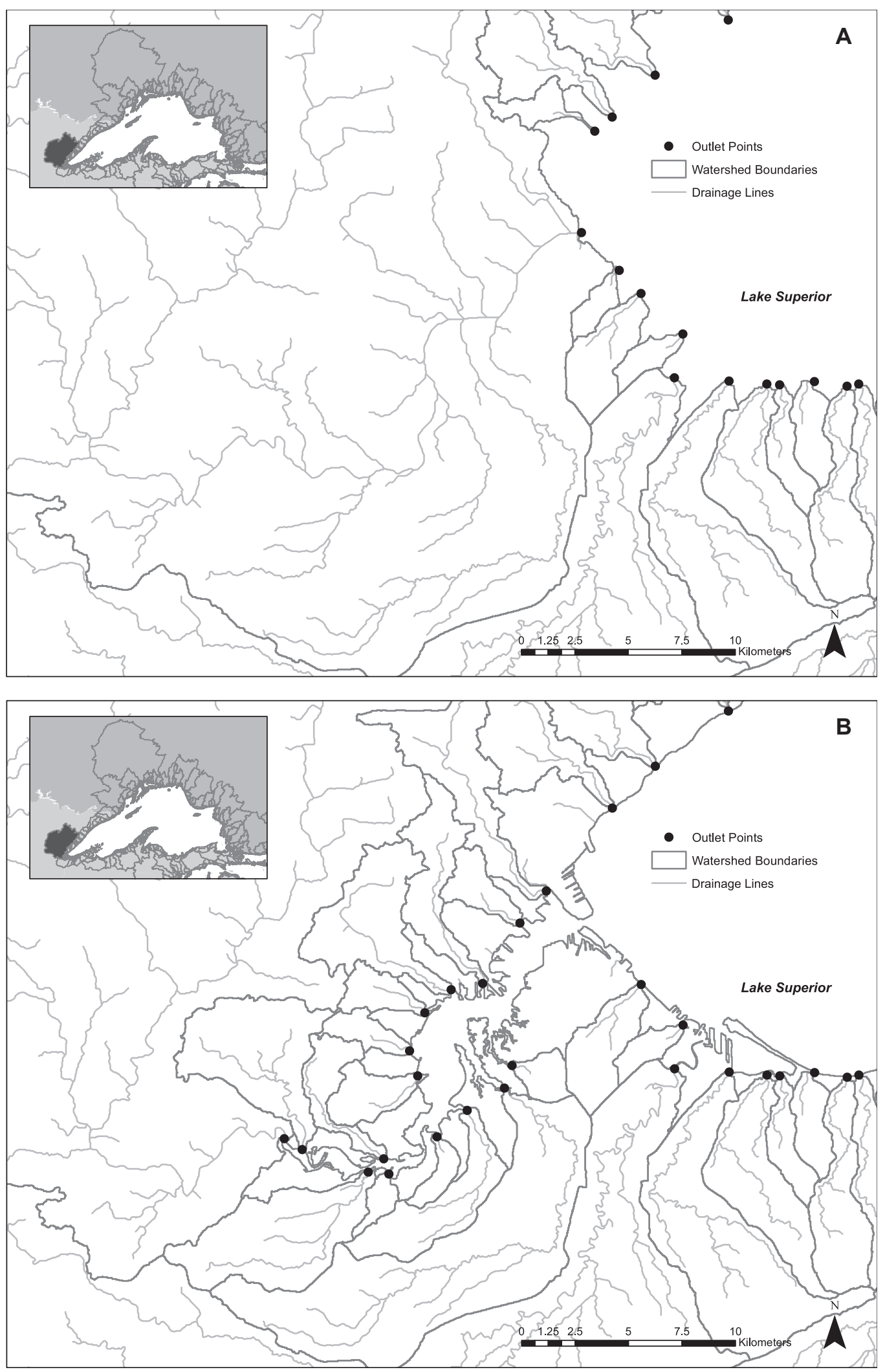

FIGURE 2. Example of Added Bay Enforcement for the St. Louis River Estuary Using the U.S. Environment Protection Agency (USEPA) Great Lakes Basin Bay Dataset. Before enforcement, (A) the watershed boundaries resulting from the unaltered National Hydrography Dataset v2 (NHDPlus v2) flow direction grid represented the estuary as a single watershed with a corresponding outlet point at the mouth of the estuary; (B) after enforcing bays from the USEPA Great Lakes Basin bay dataset, the hydrologic complexity of the estuary was captured creating numerous watersheds with outlet points and drainage lines emptying directly into the waters of the estuary. Watershed boundaries are in dark gray, synthetic drainage lines in light gray, and watershed outlet points in black. 


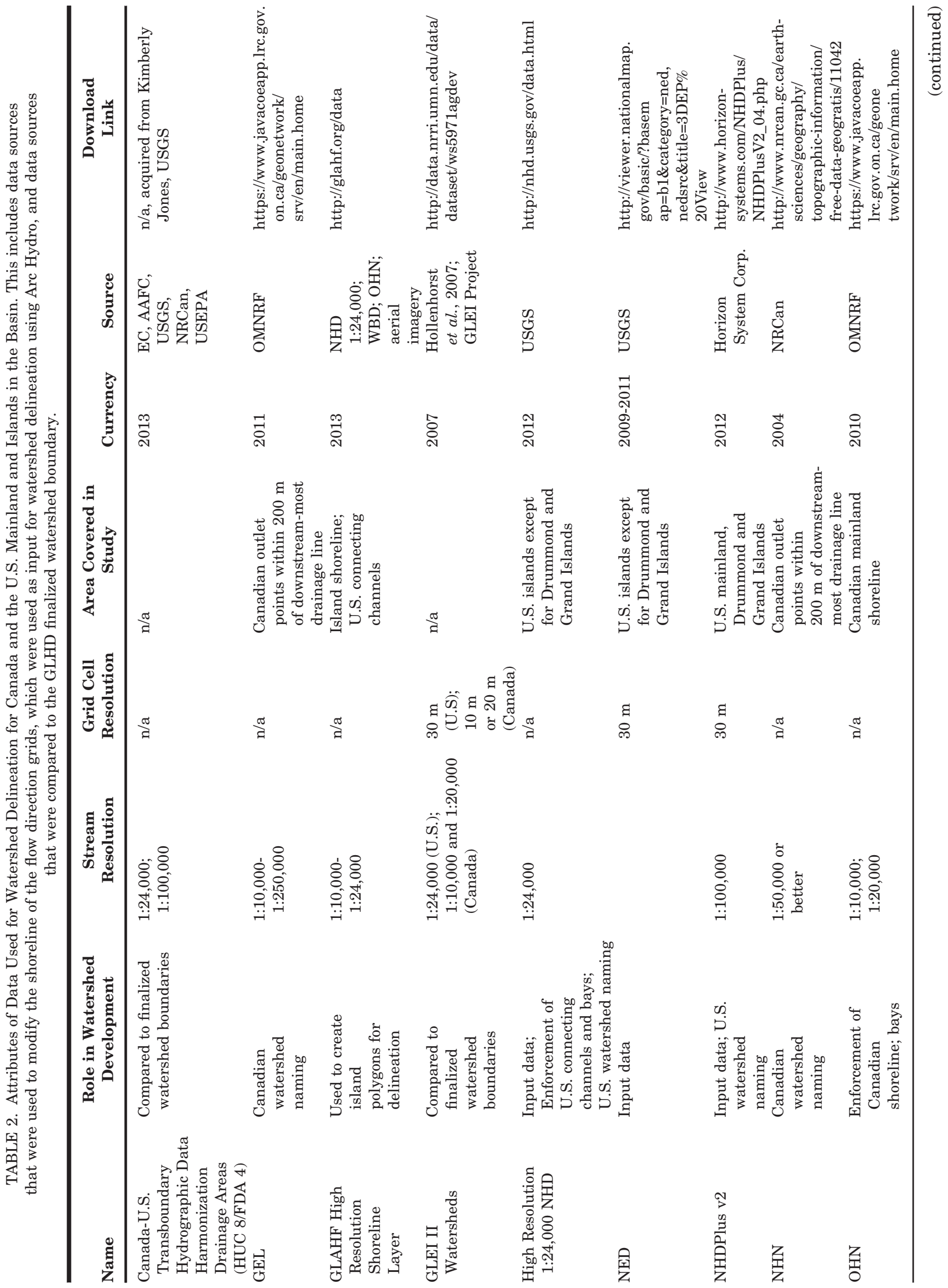




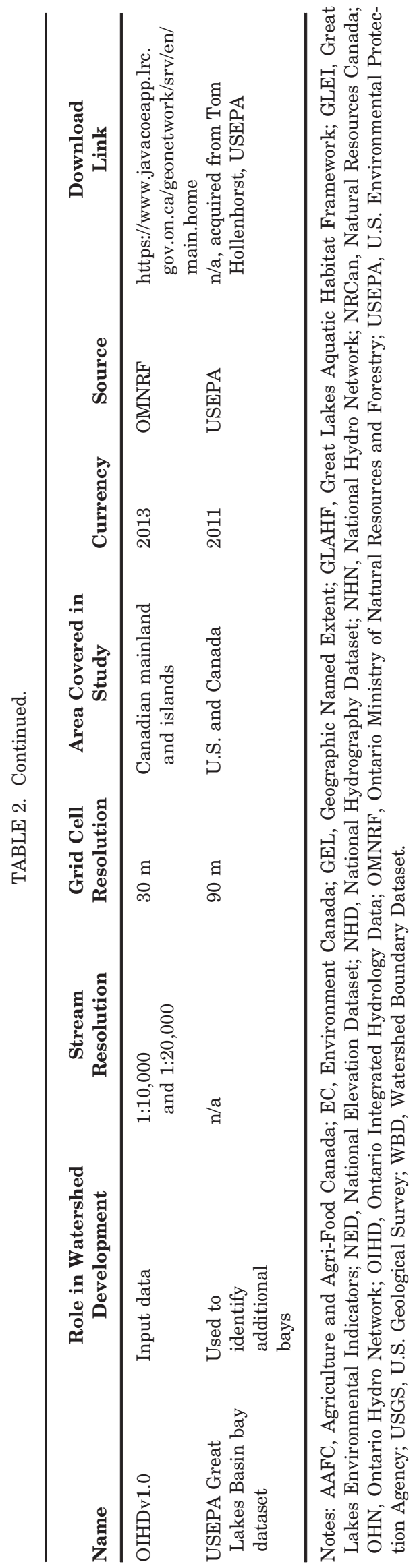

\section{RESULTS AND DISCUSSION}

\section{Characteristics of GLHD Watersheds}

The GLHD consists of watersheds for the entire Basin, covering a total area of approximately $547,967 \mathrm{~km}^{2}$, or about twice the $247,003 \mathrm{~km}^{2}$ surface water area of the Great Lakes. Summary statistics describing the 5,589 watersheds delineated across the Basin are shown in Table 4. A similar number of tributary $(N=2,354)$ and interfluve watersheds $(N=2,373)$ were delineated on the mainland. In contrast, more interfluve watersheds $(N=546)$ than tributary watersheds $(N=316)$ were delineated on islands. This occurred because most islands were too small to reach the $2.7 \mathrm{~km}^{2}$ flow accumulation threshold necessary to delineate a stream-reach and a subsequent tributary watershed boundary. Thus, watersheds on a large number of islands were represented only as interfluve watersheds. In terms of surface area, the majority of watersheds were small, and tributary watersheds tended to be larger than interfluve watersheds on both the mainland (median $=12.2 \mathrm{~km}^{2}$ vs. $2.4 \mathrm{~km}^{2}$ ) and on islands (median $=6.2 \mathrm{~km}^{2}$ vs. $2.1 \mathrm{~km}^{2}$ ). Interfluve watersheds tended to be smaller because no minimum flow accumulation threshold was used in their delineation. Although tributary watersheds accounted for $97 \%$ of the Basin in terms of land surface area, interfluve watersheds accounted for 98\% of shoreline length. Coastal development can have significant local impacts on water quality (Danz et al., 2007; U.S. Environmental Protection Agency and Environment Canada, 2009). Consequently, the GLHD consistent set of interfluve watersheds along the Great Lakes shoreline, as well as tributary watersheds, could aid coastal zone managers by providing a common framework for characterizing land use effects on coastal habitats.

The Nipigon River watershed $\left(39,149 \mathrm{~km}^{2}\right)$ in Lake Superior was the largest watershed in the Basin. The representation of the Nipigon River watershed in the GLHD was larger than other Great Lakes watershed datasets, such as the NHN, because the OIHDv1.0 included the Ogoki headwater diversions that were created to increase the net supply of water to the Great Lakes USACE, 2009). The remaining 10 largest watersheds in the Basin included the French River Eastern Outlet, Spanish River, and Trent River watersheds in Canada, and the Maumee, Fox, Saginaw, Grand, Oswego, and Saint Joseph watersheds on the U.S. side of the Basin as shown in Table 5. Nine of the 30 largest area watersheds were in the Lake Huron basin, 7 were in the Lake Michigan basin, 6 were in the Lake Superior basin, 5 were in the Lake Ontario basin, and 3 were in the Lake Erie basin. 
Forsyth, Riseng, Wehrly, Mason, Gaiot, Hollenhorst, Johnston, Wyrzykowski, Annis, Castiglone, Todd, Robertson, Infante, Wang, McKenna, and Whelan

TABLE 3. Landscape Data Variables Summarized and Compared across the GLHD Watersheds.

\begin{tabular}{|c|c|c|c|c|c|c|}
\hline Variable & Dataset & Units & Resolution & Date & Source & Download Links \\
\hline Land cover & $\begin{array}{l}\text { NLCD; } \\
\text { SOLRIS, } \\
\text { PLO }\end{array}$ & $\mathrm{km}^{2}$ & $30 \mathrm{~m} ; 25 \mathrm{~m}$ & $\begin{array}{l}2011 ; \\
2012 \\
2000\end{array}$ & $\begin{array}{l}\text { USGS; } \\
\text { OMNRF }\end{array}$ & $\begin{array}{l}\text { http://www.mrlc.gov/nlcd11_data.php; } \\
\text { https://www.javacoeapp.lrc.gov.on.ca/geonetwork/ } \\
\text { srv/en/main.home }\end{array}$ \\
\hline Population & $\begin{array}{l}\text { TIGER; } \\
\text { Census } \\
\text { profile }\end{array}$ & $\#$ & $\begin{array}{l}\text { Tract; } \\
\text { Subdivision }\end{array}$ & $\begin{array}{r}2010 \\
2011\end{array}$ & $\begin{array}{l}\text { U.S. Census } \\
\text { Bureau; } \\
\text { Statistics } \\
\text { Canada }\end{array}$ & $\begin{array}{l}\text { http://www.census.gov/geo/maps- } \\
\text { data/data/tiger.html; } \\
\text { http://www12.statcan.gc.ca/census- } \\
\text { recensement/index-eng.cfm }\end{array}$ \\
\hline Roads & $\begin{array}{l}\text { TIGER; } \\
\text { Road } \\
\text { network } \\
\text { files }\end{array}$ & $\mathrm{km}$ & $1: 100,000$ & $\begin{array}{r}2013 \\
2014\end{array}$ & $\begin{array}{l}\text { U.S. Census } \\
\text { Bureau; } \\
\text { Statistics } \\
\text { Canada }\end{array}$ & $\begin{array}{l}\text { http://www.census.gov/geo/maps-data/data/tiger- } \\
\text { geodatabases.html; } \\
\text { http://www12.statcan.gc.ca/census- } \\
\text { recensement/2011/geo/RNF-FRR/index-2011- } \\
\text { eng.cfm }\end{array}$ \\
\hline
\end{tabular}

Notes: NLCD, National Land Cover Dataset; OMNRF, Ontario Ministry of Natural Resources and Forestry; PLO, Provincial Land cover Ontario; SOLRIS, Southern Ontario Land Resource Information System; TIGER, Topologically Integrated Geographic Encoding and Referencing; USGS, U.S. Geological Survey.

TABLE 4. Area Summaries of the GLHD for Tributary and Interfluve Watershed Boundaries. Island and mainland watershed summaries are shown for the entire Great Lakes Basin (GL Basin) and by major lake basin.

\begin{tabular}{|c|c|c|c|c|}
\hline & Number & $\begin{array}{c}\text { Minimum } \\
\text { Area }\left(\mathbf{k m}^{2}\right)\end{array}$ & $\begin{array}{c}\text { Median } \\
\text { Area }\left(\mathbf{k m}^{2}\right)\end{array}$ & $\begin{array}{c}\text { Maximum } \\
\text { Area }\left(\mathbf{k m}^{2}\right)\end{array}$ \\
\hline \multicolumn{5}{|c|}{ Mainland tributary } \\
\hline GL Basin & 2,354 & 2.7 & 12.2 & $39,149.1$ \\
\hline Erie & 380 & 2.7 & 13.8 & $16,971.0$ \\
\hline Huron & 581 & 2.7 & 8.9 & $16,129.2$ \\
\hline Michigan & 293 & 2.8 & 19.1 & $16,468.9$ \\
\hline Ontario & 432 & 2.7 & 12.7 & $13,218.3$ \\
\hline Superior & 668 & 2.7 & 11.9 & $39,149.1$ \\
\hline \multicolumn{5}{|c|}{ Island tributary } \\
\hline GL Basin & 316 & 2.7 & 6.2 & 336.8 \\
\hline Erie & 17 & 3.5 & 6.6 & 17.9 \\
\hline Huron & 175 & 2.8 & 6.5 & 336.8 \\
\hline Michigan & 24 & 2.8 & 5.0 & 19.6 \\
\hline Ontario & 18 & 2.7 & 6.3 & 26.6 \\
\hline Superior & 82 & 2.8 & 5.3 & 72.7 \\
\hline \multicolumn{5}{|c|}{ Mainland interfluve } \\
\hline GL Basin & 2,373 & $<0.1$ & 2.4 & 288.4 \\
\hline Erie & 395 & $<0.1$ & 1.7 & 231.6 \\
\hline Huron & 582 & $<0.1$ & 2.2 & 288.4 \\
\hline Michigan & 284 & $<0.1$ & 4.2 & 177.3 \\
\hline Ontario & 447 & $<0.1$ & 1.9 & 46.0 \\
\hline Superior & 665 & $<0.1$ & 2.9 & 148.2 \\
\hline \multicolumn{5}{|c|}{ Island interfluve } \\
\hline GL Basin & 546 & $<0.1$ & 2.1 & 203.3 \\
\hline Basin & 60 & $<0.1$ & 0.6 & 15.4 \\
\hline Huron & 308 & $<0.1$ & 1.9 & 203.3 \\
\hline Michigan & 26 & $<0.1$ & 3.7 & 18.5 \\
\hline Ontario & 33 & $<0.1$ & 0.7 & 75.6 \\
\hline Superior & 119 & $<0.1$ & 4.0 & 33.5 \\
\hline
\end{tabular}

Using the GLHD Watershed Layer to Summarize Basin Wide Data

The GLHD watersheds provide a framework to summarize and compare landscape characteristics consistently across the Basin. Because the GLHD includes detail for embayments not included in other watershed datasets and delineated watersheds for island and tributaries draining to connecting channels, the GLHD watersheds allow for more accurate and spatially comprehensive data summaries. The GLHD watershed layer was used to summarize a set of landscape variables across all watersheds in the Basin. Due to the large number of watersheds, summary tables were only included for the 30 largest watersheds (Tables 5 and 6; Figure 3); summaries are available for all Basin watersheds (see Supporting Information).

Forest (42\%) and agriculture (23\%) were the predominant land use types across all watersheds in the Basin, followed by urban land use (13\%) and wetlands (12\%). Forested land cover was concentrated in the northern half of the basin and was the predominant land cover in the Lake Superior (75\%) and Lake Huron (46\%) basins. Agriculture was concentrated in the southern half of the basin and was highest in the Lake Erie (41\%), Lake Ontario (39\%), and Lake Huron (24\%) basins. Six percent of the watersheds in the Basin were comprised of more than $80 \%$ agricultural lands, and $17 \%$ were comprised of more than $60 \%$ agricultural lands. In the Lake Erie basin, a large number of watersheds including the Syndenham (84\%) and Thames Rivers $(80 \%)$ in Canada and the Portage (81\%), Sandusky (81\%), and Maumee Rivers (78\%) in the U.S. were dominated by agricultural land use. Wetlands were most common in the Lake Michigan (24\%), Lake Erie (14\%), and Lake Ontario (13\%) basins.

Like agriculture, urban land use, road density, and population densities tend to be concentrated in the southern portion of the Basin near metropolitan hubs like Chicago, Illinois; Milwaukee, Wisconsin; Detroit, Michigan; and Toledo and Cleveland, Ohio in the U.S. and Toronto, Ontario in Canada. About 30\% of 
The Great Lakes Hydrography Dataset: Consistent, Binational Watersheds for the Laurentian Great Lakes Basin

TABLE 5. GLHD Watershed Statistics, Road Density, and Population Summaries for the 30 Largest Watersheds in the Basin.

\begin{tabular}{|c|c|c|c|c|c|}
\hline Watershed Name & Lake Basin & Country & $\begin{array}{c}\text { Watershed Area } \\
\qquad\left(\mathbf{k m}^{2}\right)\end{array}$ & $\begin{array}{c}\text { Road Density } \\
\left(\mathbf{k m} / \mathbf{k m}^{2}\right)\end{array}$ & $\begin{array}{c}\text { Population } \\
\left(\# / \mathbf{k m}^{2}\right)\end{array}$ \\
\hline Nipigon River & Superior & Canada & 39,149 & 0.1 & $<1$ \\
\hline Maumee River & Erie & United States & 16,971 & 2.1 & 64 \\
\hline Fox River & Michigan & United States & 16,469 & 1.6 & 48 \\
\hline Saginaw River & Huron & United States & 16,129 & 2.0 & 74 \\
\hline Eastern Outlet (French River) & Huron & Canada & 15,489 & 0.4 & 5 \\
\hline Grand River & Michigan & United States & 14,456 & 2.2 & 108 \\
\hline Spanish River & Huron & Canada & 13,646 & 0.3 & 8 \\
\hline Oswego River & Ontario & United States & 13,218 & 1.9 & 79 \\
\hline Trent River & Ontario & Canada & 12,591 & 1.1 & 23 \\
\hline Saint Joseph River & Michigan & United States & 12,226 & 2.2 & 79 \\
\hline Menominee River & Michigan & United States & 10,535 & 1.2 & 6 \\
\hline Mississagi River & Huron & Canada & 9,277 & 0.2 & $<1$ \\
\hline Saint Louis River & Superior & United States & 9,259 & 0.9 & 11 \\
\hline Kaministiquia River (Dog) & Superior & Canada & 7,834 & 0.3 & 3 \\
\hline Muskegon River & Michigan & United States & 7,062 & 2.0 & 34 \\
\hline Grand River & Erie & Canada & 6,773 & 1.6 & 151 \\
\hline Genesee River & Ontario & United States & 6,454 & 1.8 & 63 \\
\hline Severn River-Lake Simcoe & Huron & Canada & 6,043 & 1.1 & 82 \\
\hline Thames River & Erie & Canada & 5,664 & 1.6 & 94 \\
\hline Michipicoten River & Superior & Canada & 5,368 & 0.1 & $<1$ \\
\hline Old Au Sable River & Huron & United States & 5,304 & 2.2 & 11 \\
\hline Kalamazoo River & Michigan & United States & 5,272 & 2.2 & 89 \\
\hline White River & Superior & Canada & 5,228 & 0.1 & $<1$ \\
\hline Manistee River & Michigan & United States & 5,050 & 1.9 & 12 \\
\hline Black River & Ontario & United States & 4,961 & 0.9 & 12 \\
\hline Moon River (Muskoka) & Huron & Canada & 4,948 & 0.8 & 9 \\
\hline Pic River & Superior & Canada & 4,359 & 0.2 & 1 \\
\hline Oswegatchie River & Ontario & United States & 4,188 & 0.9 & 14 \\
\hline Saugeen River & Huron & Canada & 3,990 & 1.0 & 17 \\
\hline Wanapitei River & Huron & Canada & 3,871 & 0.2 & 13 \\
\hline
\end{tabular}

watersheds contained $10 \%$ or more urban land use and $62 \%$ of those were located in the U.S. Approximately $19 \%$ of the watersheds contained $20 \%$ or more urban land, including the Clinton, Cuyahoga, and River Rouge basins on the U.S. side of the Lake Erie basin, and the Kinnickinnic River draining to Lake Michigan. These watersheds also had high road densities (the length of road per $\mathrm{km}^{2}$ of watershed area) ranging from 3.8 to $8.6 \mathrm{~km} / \mathrm{km}^{2}$. Road densities and urban land cover percentages were also high in the Humber $\left(3.4 \mathrm{~km} / \mathrm{km}^{2}\right.$ and $31 \%)$ and Credit River $\left(2 \mathrm{~km} / \mathrm{km}^{2}\right.$ and $\left.24 \%\right)$ watersheds near Toronto. About $2 \%$ of watersheds in the Basin had a population density greater than 1,000 people $/ \mathrm{km}^{2}$ including watersheds of large metropolitan areas such as the Ecorse and Rouge Rivers near Detroit, small watersheds associated with Cleveland, and Buffalo and Rochester, New York in the Lake Erie basin, and the Humber and Don River watersheds draining to Lake Ontario. Approximately $14 \%$ of watersheds had a population density between 100 and 1,000 people/ $\mathrm{km}^{2}$, including the Grand River near Grand Rapids, Michigan, the Kinnickinnic River near Milwaukee, and other tributary watersheds near Hamilton and Toronto, Ontario, including the Grand River basin.

\section{Comparison of GLHD Watersheds to Other Great Lakes Watershed Layers}

A number of GIS-based watershed layers have been created that only cover the U.S. or the Canadian side of the Basin. Currently, only three major broad-scale international watershed layers exist: the HydroSHEDS drainage areas, the Canada-U.S. Transboundary Hydrographic Data Harmonization drainage areas, and the GLEI II watersheds.

The HydroSHEDS project, led by the Conservation Science Program of the World Wildlife Fund, provides consistent, Basin wide hydrography data, including flow direction grids, flow accumulation grids, a river network, and drainage basins (Lehner, 2006). The HydroSHEDS effort differs from the GLHD in that it provides hydrography information at the global scale. Consequently, spatial resolution of the HydroSHEDS data is much coarser than the NHDPlus v2 and OIHDv1.0, and the Basin is represented as a single watershed in the drainage area layer.

The Canada-U.S. Transboundary Hydrographic Data Harmonization project, convened by the International Joint Commission, is working to harmonize 
Forsyth, Riseng, Wehrly, Mason, Gaiot, Hollenhorst, Johnston, Wyrzykowski, Annis, Castiglione, Todd, Robertson, Infante, Wang, McKenna, and Whelan

TABLE 6. Percentage of Land Cover Type in the 30 Largest GLHD Watersheds in the Basin.

\begin{tabular}{|c|c|c|c|c|c|c|c|c|c|}
\hline Name & $\begin{array}{c}\% \\
\text { Urban }\end{array}$ & $\begin{array}{c}\% \\
\text { Agriculture }\end{array}$ & $\begin{array}{c}\% \\
\text { Water }\end{array}$ & $\begin{array}{c}\% \\
\text { Barren }\end{array}$ & $\begin{array}{c}\% \\
\text { Forest }\end{array}$ & $\begin{array}{c}\% \\
\text { Scrub } \\
\text { Shrub }\end{array}$ & $\begin{array}{c}\% \\
\text { Grassland/ } \\
\text { Herbaceous }\end{array}$ & $\begin{array}{c}\% \\
\text { Wetland }\end{array}$ & $\begin{array}{c}\% \\
\text { No Data }\end{array}$ \\
\hline Nipigon River & 0.1 & $<0.1$ & 23.8 & $<0.1$ & 64.1 & 0.4 & 7.5 & 3.5 & 0.6 \\
\hline Maumee River & 11.5 & 77.5 & 0.8 & 0.1 & 6.8 & 0.1 & 1.0 & 2.2 & $<0.1$ \\
\hline Fox River & 8.4 & 41.5 & 6.3 & 0.1 & 24.6 & 0.4 & 0.6 & 18.0 & $<0.1$ \\
\hline Saginaw River & 12.7 & 45.2 & 1.4 & 0.3 & 22.6 & 1.1 & 2.8 & 13.8 & $<0.1$ \\
\hline Eastern Outlet (French River) & 0.8 & 3.5 & 15.5 & 0.8 & 75.6 & $<0.1$ & 0.9 & 2.8 & 0.2 \\
\hline Grand River & 14.8 & 53.4 & 1.5 & 0.4 & 16.6 & 0.3 & 0.9 & 12.0 & $<0.1$ \\
\hline Spanish River & 1.6 & 1.1 & 10.1 & 3.0 & 77.9 & $<0.1$ & 4.4 & 1.9 & $<0.1$ \\
\hline Oswego River & 8.3 & 39.5 & 6.4 & 0.2 & 30.5 & 6.4 & 0.8 & 7.9 & $<0.1$ \\
\hline Trent River & 3.2 & 28.4 & 9.6 & 0.3 & 43.7 & $<0.1$ & 0.1 & 14.6 & 0.2 \\
\hline Saint Joseph River & 13.7 & 58.6 & 2.3 & 0.2 & 11.4 & 0.3 & 1.0 & 12.4 & $<0.1$ \\
\hline Menominee River & 3.9 & 4.3 & 2.9 & 0.1 & 53.5 & 2.0 & 2.4 & 30.9 & $<0.1$ \\
\hline Mississagi River & 0.1 & 0.3 & 10.5 & 0.5 & 81.5 & $<0.1$ & 5.2 & 2.0 & $<0.1$ \\
\hline Saint Louis River & 3.2 & 3.2 & 3.8 & 1.2 & 33.7 & 7.3 & 1.3 & 46.3 & $<0.1$ \\
\hline Kaministiquia River (Dog) & 0.4 & 1.0 & 10.3 & 0.1 & 76.1 & $<0.1$ & 8.2 & 3.6 & 0.2 \\
\hline Muskegon River & 8.5 & 19.5 & 4.2 & 0.2 & 39.5 & 3.1 & 7.0 & 18.0 & $<0.1$ \\
\hline Grand River & 9.0 & 71.6 & 0.9 & 0.4 & 6.0 & $<0.1$ & $<0.1$ & 12.2 & $<0.1$ \\
\hline Genesee River & 7.2 & 44.9 & 0.9 & 0.2 & 37.7 & 3.7 & 0.4 & 5.1 & $<0.1$ \\
\hline Severn River-Lake Simcoe & 5.9 & 30.2 & 16.8 & 1.6 & 33.0 & $<0.1$ & 0.2 & 12.2 & 0.1 \\
\hline Thames River & 8.1 & 79.9 & 0.7 & 0.3 & 6.0 & $<0.1$ & $<0.1$ & 4.9 & $<0.1$ \\
\hline Michipicoten River & 0.1 & $<0.1$ & 13.9 & $<0.1$ & 79.3 & $<0.1$ & 4.0 & 2.2 & 0.5 \\
\hline Old Au Sable River & 8.5 & 3.3 & 2.0 & 0.1 & 55.9 & 10.0 & 7.6 & 12.8 & $<0.1$ \\
\hline Kalamazoo River & 13.7 & 48.0 & 2.3 & 0.5 & 21.4 & 0.4 & 1.4 & 12.4 & $<0.1$ \\
\hline White River & $<0.1$ & $<0.1$ & 10.6 & 0.5 & 78.1 & $<0.1$ & 8.6 & 2.0 & 0.1 \\
\hline Manistee River & 6.0 & 9.0 & 1.4 & 0.2 & 55.4 & 5.1 & 11.3 & 11.7 & $<0.1$ \\
\hline Black River & 1.7 & 11.8 & 3.9 & 0.2 & 66.5 & 7.8 & 1.1 & 7.1 & $<0.1$ \\
\hline Moon River (Muskoka) & 1.7 & 2.7 & 16.8 & 0.7 & 76.4 & $<0.1$ & $<0.1$ & 1.6 & 0.2 \\
\hline Pic River & $<0.1$ & $<0.1$ & 6.3 & $<0.1$ & 86.6 & $<0.1$ & 5.6 & 1.3 & 0.2 \\
\hline Oswegatchie River & 2.7 & 13.4 & 4.5 & 0.1 & 60.7 & 2.6 & 2.4 & 13.6 & $<0.1$ \\
\hline Saugeen River & 3.0 & 66.8 & 0.8 & 0.2 & 10.1 & $<0.1$ & $<0.1$ & 19.2 & $<0.1$ \\
\hline Wanapitei River & 1.0 & $<0.1$ & 10.4 & 5.1 & 75.8 & $<0.1$ & 4.4 & 3.3 & $<0.1$ \\
\hline
\end{tabular}

stream networks, water features such as lakes, ponds, and reservoirs, and nested hydrologic units for drainage areas that cross the international boundary (Laitta, 2010). Unlike the GLHD, the Canada-U.S. Transboundary Hydrographic Data Harmonization project combines existing watershed boundaries that were developed using different methods for those hydrologic units that straddle the international border. In contrast, the GLHD used a consistent method to delineate comparable watersheds across the entire Basin. In addition, the Canada-U.S. Transboundary Hydrographic Data Harmonization drainage areas currently do not provide the same detail as the GLHD because interfluve watersheds are lumped with tributary watersheds, and watersheds are generalized in connecting channels as shown in Figure 4A and 4B. At this time, the Canada-U.S. Transboundary Hydrographic Data Harmonization project does not provide a consolidated data package that incorporates the harmonized drainage areas, streams, and water features, along with the rest of the data for the entire Basin.

The GLEI II watersheds are nested, tributary watersheds that were created for the U.S. side of the Basin (Danz et al., 2007; Hollenhorst et al., 2007) and subsequently expanded to the Canadian side of the Basin, in an unpublished effort in which a co-author on this article participated (Tom Hollenhorst, USEPA, 23 July, 2012, personal communication). The GLEI II watershed data layer is most similar to the GLHD in that it provides consistent Basin wide coverage, was created using similar delineation methods in the U.S. and Canada, and provides interfluve watersheds in addition to tributary watersheds. The GLHD differs from the GLEI II watersheds in several key ways: updated and externally validated flow direction grid across the Basin; consistent island stream networks and watersheds; input from a binational panel of hydrology experts; and, public access to consistent, nested watershed layers and related data in one package. The different hydrography input data used to delineate watersheds is a key difference between the GLEI II watersheds and the GLHD watersheds. The GLHD watersheds were based on the most current NHDPlus v2 (U.S.) and the OIHDv1.0 (Canada) which both include expert verified and hydrologically corrected flow direction grids. The GLEI II project developed flow direction grids using the high resolution NHD to hydrologically correct the $30 \mathrm{~m}$ NED for the 


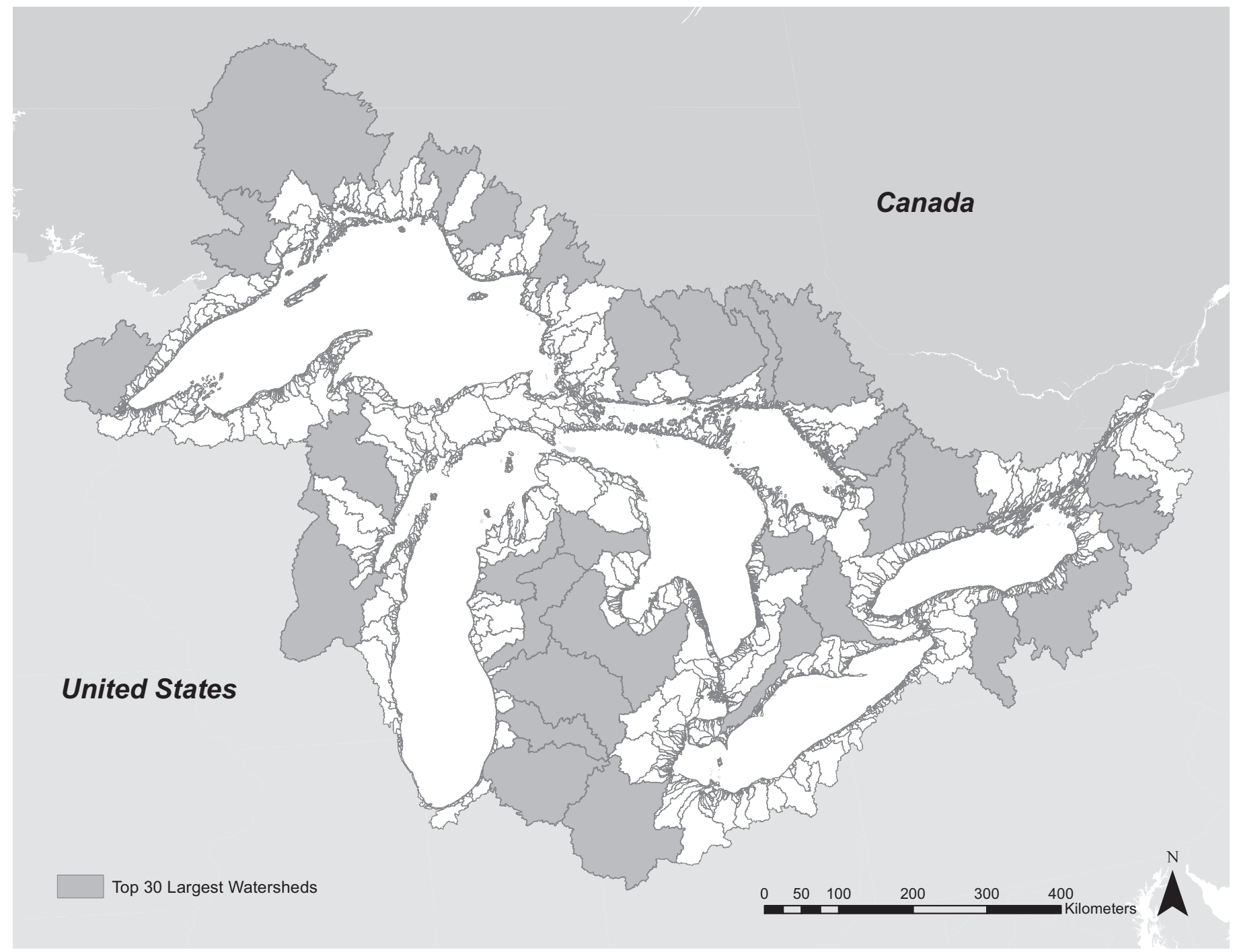

FIGURE 3. GLHD Basin Wide Watershed Boundaries. This includes partial coverage of the St. Lawrence Seaway with the 30 largest watersheds shaded in gray.

U.S. tributaries. Unlike the NHDPlus v2 flow direction grids used to develop the GLHD watershed boundaries on the U.S. side of the basin, the resulting GLEI II flow direction grid was not reviewed by experts. The subsequent Canadian portion of the GLEI II watersheds used the expertly verified streamenforced elevation data from the 2002 Provincial Digital Elevation Model (DEM) of the Provincial Watershed Project that was intended for watershed delineation (OMNR, 2002). However, the 2002 Provincial DEM has been retired and subsequently replaced by a series of updated hydrography data, the most current of which is the OIHDv1.0.

There are a number of noteworthy characteristics of the GLHD. First, the GLHD used expert-verified flow direction grids, and relied on a binational team of experts to iteratively review and provide input at each step of the delineation process to improve the accuracy of the Basin wide GLHD watersheds. Second, the GLHD uniquely developed a comprehensive package of publically available watershed boundaries that includes stream networks, reach catchments, watershed boundaries, a broad set of attribute data for each tributary, and metadata that documents methodology. Finally, the GLHD also uniquely expanded the number of unique features such as islands and estuaries which will enhance research and management in the Basin. For example, inventory and conservation efforts focused on Great Lakes islands is a growing area of interest for federal, state, and provincial agencies (Penskar et al., 2002). Likewise, inclusion of major Great Lakes estuaries in the GLHD will facilitate assessment and evaluation of tributary influences on estuary processes. For example, the St. Louis River estuary, shown in Figure 2, is a National Estuarine Research Reserve (NOAA, 2015) that represents an 

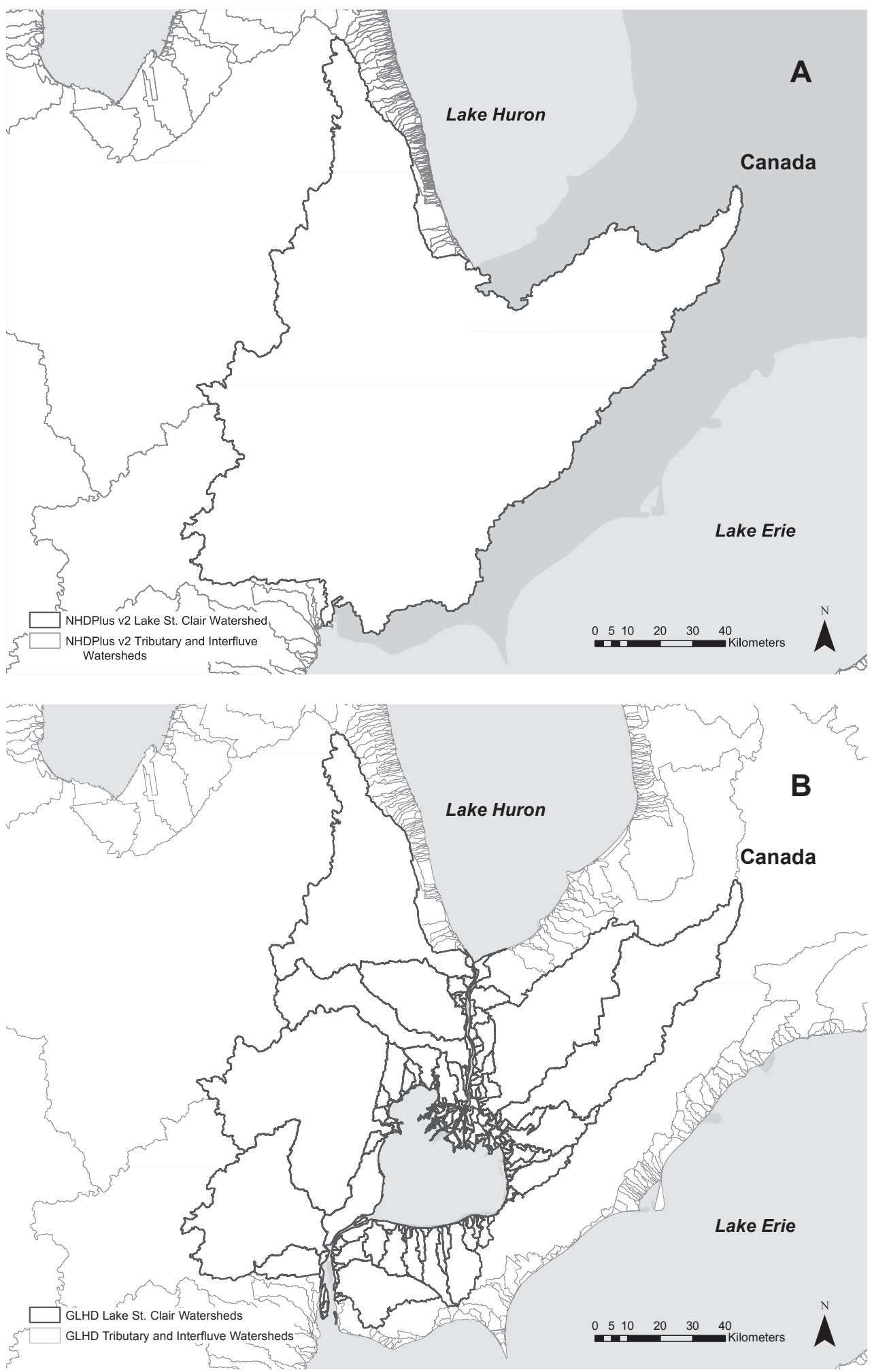

FIGURE 4. Comparison of the National Hydrography Dataset Plus v2 (NHDPlus v2) and GLHD Derived Watershed Boundaries in the St. Clair Detroit River System (SCDRS) Connecting Channel between Lake Huron and Lake Erie. In Panels A and B, the dark gray lines indicate the watershed/s corresponding to the SCDRS, and the light gray lines represent the rest of the watersheds outside of the connecting channel. Panel A shows how the NHDPlus v2 generalizes watershed boundaries in the connecting channels, whereas Panel B shows how the GLHD watershed boundaries empty directly into the waters of the connecting channel. In Panels $\mathrm{C}$ and $\mathrm{D}$, reach catchments are represented by the dark gray lines and drainage lines are indicated in light gray, with the shoreline outlined in medium gray. Panels C and D depict a small coastal reach catchment near Sandusky, Ohio that drains into Sandusky Bay in Lake Erie and illustrates minor stream and reach catchment differences between the NHDPlus v2 (C) and the GLHD (D) due to the GLHD threshold processing methods. 


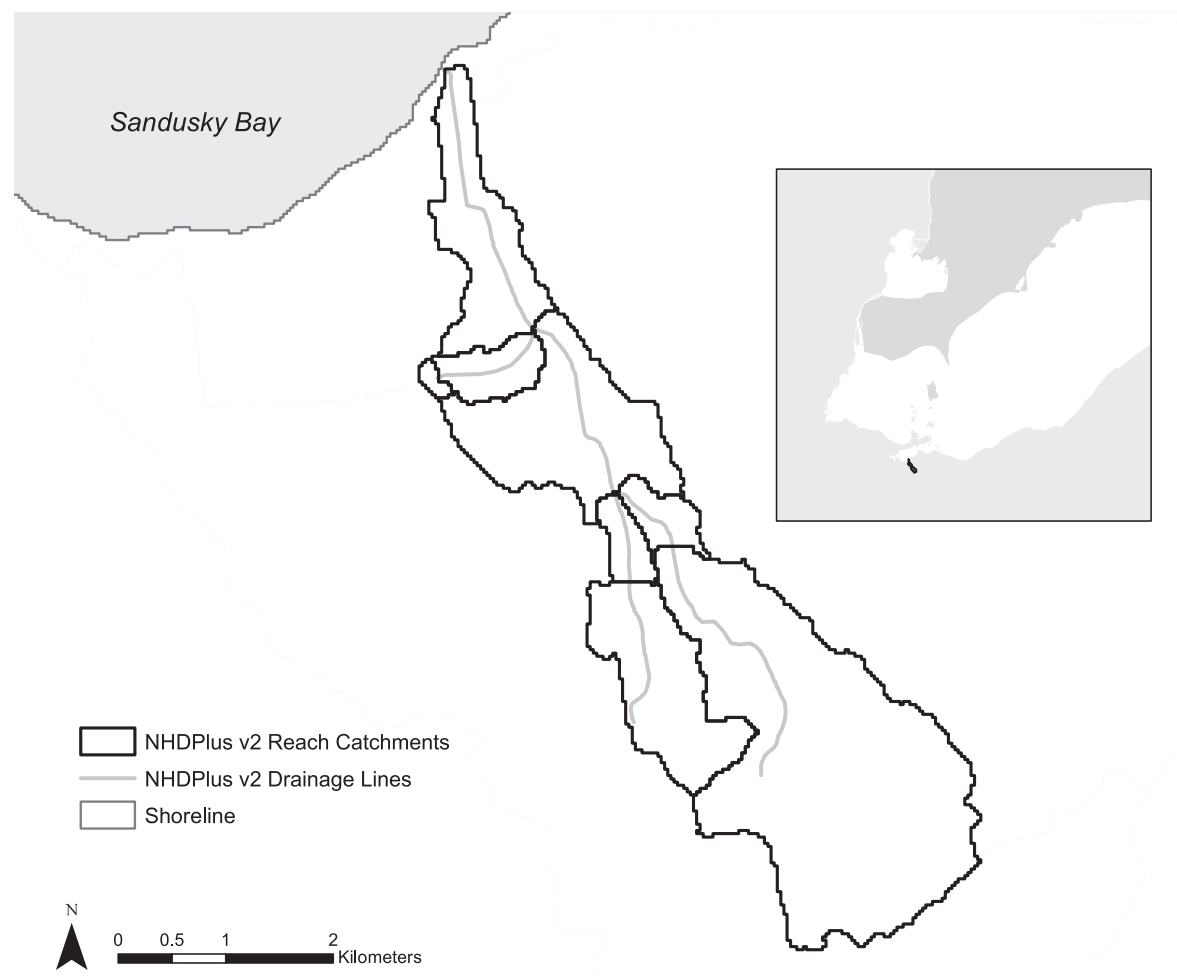

C

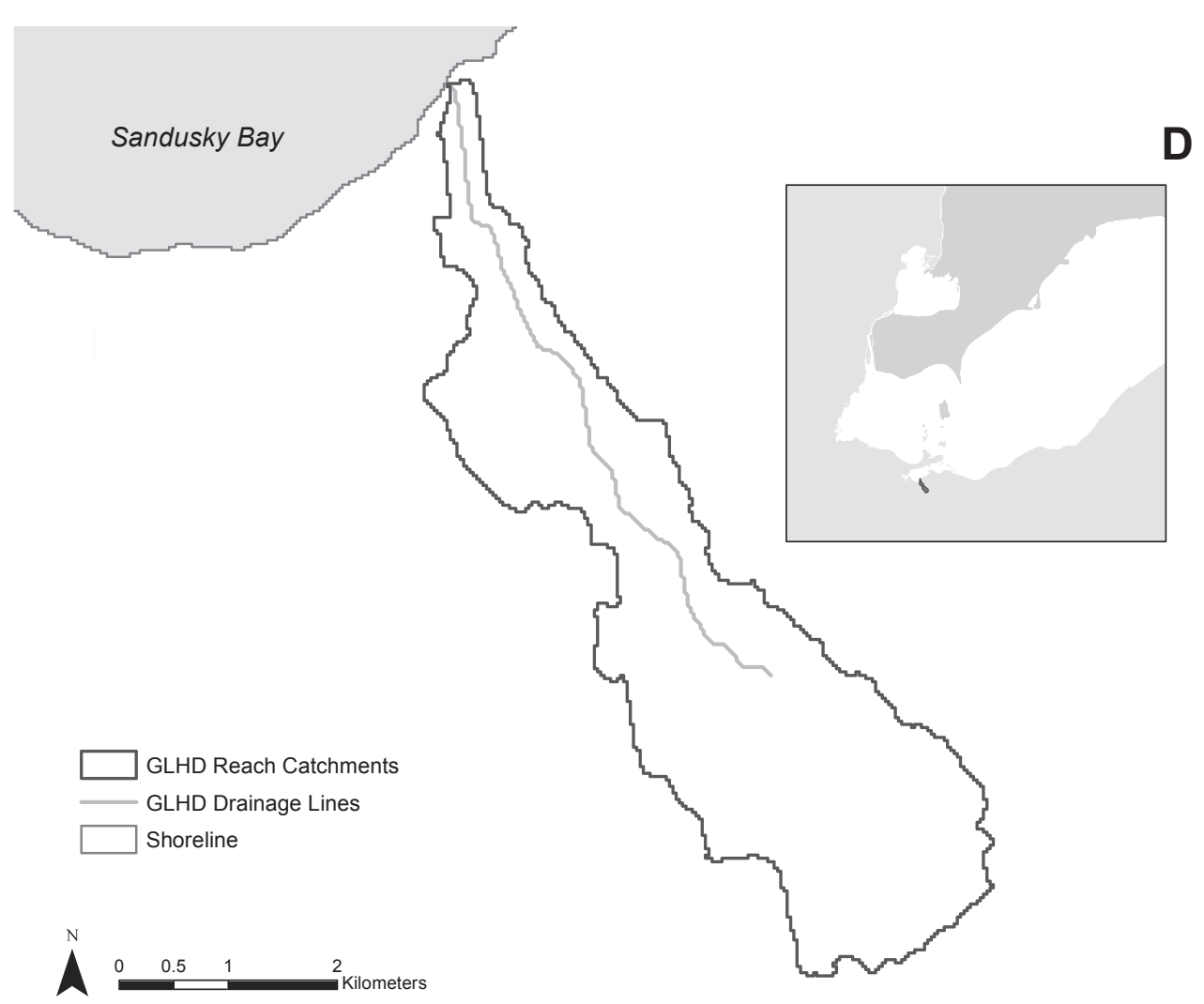

FIGURE 4. Continued. 
important freshwater estuary in the Reserve system. Delineation of tributary watersheds to the St. Louis estuary will enhance efforts to assess human influences on coastal resources.

\section{GLHD Validation}

To ensure the methods used to create the GLHD accurately reproduced watershed boundaries across the Basin at the scale of the NHDPlus v2, the GLHD U.S. watersheds were compared to the NHDPlus v2 tributary watersheds developed by aggregating NHDPlus v2 reach catchments. The GLHD watersheds were not compared to the Canadian OIHDv1.0 watersheds because the OIHDv1.0 watersheds were not bounded at the shoreline and extended into the Great Lakes. In addition, interfluves were not identified in the OIHDv1.0 but were merged together with the tributary watersheds at the coast. Thus, the OIHDv1.0 watersheds were not spatially comparable to the GLHD watersheds. When comparing the GLHD watershed to the NHDPlus v2 watersheds, the vast majority (96\%) of the GLHD U.S. tributary watersheds were within $1 \%$ of the surface area of the aggregated tributary watersheds in the NHDPlus v2, excluding those areas where the GLHD watershed layer enhanced the NHDPlus v2 (connecting channel watersheds, enforced embayments, and estuaries). On the basis of the results of this comparison, we determined the GLHD delineation method created Canadian watersheds that were also comparable to the NHDPlus v2 watersheds in spatial scale.

The main difference between the NHDPlus v2 and GLHD watershed boundaries occurred in coastal areas resulting from the $2.7 \mathrm{~km}^{2}$ upstream stream-reach threshold and the shoreline modifications outlined in the methods section of this manuscript. The NHDPlus v2 identified artificial channels (e.g., agricultural drainage ditches) in addition to the main channel, while the GLHD thresholding procedure only identified the main channel. In some cases this resulted in more watersheds being identified in the NHDPlus v2 than in the GLHD. Along the coastline, interfluve watershed boundaries differed because the NHDPlus v2 tributary outlet points are inland of the shoreline creating one narrow continuous band along the shoreline that links the interfluves. In contrast, the GLHD represented watersheds outlet points at the coast, and separate interfluves between each watershed outlet point.

While the GLHD watershed boundaries were similar to the aggregated NHDPlus v2 watershed boundaries, the GLHD individual reach catchment boundaries may differ. Due to the area threshold used to create the synthetic stream reaches, the GLHD synthetic drainage network was sometimes more detailed and sometimes less detailed than the NHDPlus v2 drainage network, which was hand digitized from USGS 1:100,000 scale topographic maps (Johnston et al., 2009). This resulted in some differences in corresponding reach catchment boundaries, for example, either multiple NHDPlus v2 reach catchments in a GLHD reach catchment or vice versa as shown in panels C and D of Figure 4.

We were confident that although the source hydrography differed in scale between the NHDPlus v2 and the OIHDv1.0, delineated watersheds were comparable across the U.S and Canada. The finer scale of the OHIDv1.0 stream networks (1:10,000 and 1:20,000 vs. $1: 100,000)$ resulted in a more complex drainage network, which included more headwater streams and meanders. This detail was reflected in the OHIDv1.0 flow direction grid since the flow direction grid represented the drainage network. However, variability in spatial scale of the input data was mitigated using flow direction grids with $30 \mathrm{~m}$ grid cells, which helped to generalize (remove excess detail from) the network, and using a consistent size threshold to create stream networks. The threshold generalized the synthetic networks created from the flow direction grids by removing most of the small headwater streams resulting in drainage networks with similar headwater extent resolution. Confluence-to-confluence reach catchment area in the U.S. (mean $=4.998 \mathrm{~km}^{2}, \mathrm{SE}=0.016$ ) and Canada (mean $=5.007 \mathrm{~km}^{2}, \mathrm{SE}=0.018$ ) were similar, indicating the effects of scale differences in source hydrography on reach catchment size and resulting watershed areas were negligible.

\section{Use and Public Availability}

An important objective of this project was to provide a publically accessible and consistent dataset for summarizing watershed characteristics across the mainland and island areas within the entire Basin for use in characterizing watershed influences on Great Lakes nearshore and offshore habitats. The GLHD GIS data are available as part of the GLHDv1.0 data package that is stored in an Esri file geodatabase with associated documentation and can be downloaded from the GLAHF website at: http://glahf.org/watersheds/. The geodatabase includes the watershed and interfluve boundaries along with watershed outlet points, the synthetic intermediate data layers created in the Arc Hydro processing steps, modified versions of the NHDPlus v2, OIHDv1.0, and NHD drainage networks, and a modified version of the NHDPlus v2 reach catchments. The GLHD watershed layer provides Canadian tributary watershed boundaries that are comparable to the NHDPlus v2 watershed boundaries. 
The watershed and interfluve boundaries and watershed outlet points are also accessible to the public from a web viewer (http://glahf.org/explorer/).

The watershed boundaries and associated layers are current to the time period of publication for each data source. The GLHD is scheduled to be updated at specific time steps (five years at a minimum) or based on significant changes to the input datasets. The OIHDv1.0, NHDPlus v2, and NHD drainage networks and the NHDPlus v2 reach catchments are created by federal and provincial agencies and are incorporated into a number of projects throughout the region. For projects using NHDPlus v2 or OIHDv1.0 hydrography data, the modified versions of those layers that are included in the GLHD data package should be used over the synthetic GLHD drainage network and reach catchments that were created using Arc Hydro. However, if Basin wide applications require similar scale drainage networks or reach catchments, the GLHD synthetic layers may be applicable and useful, and can be linked back to the original NHDPlus v2, OIHDv1.0, or NHD drainage lines or the NHDPlus v2 reach catchments. Additionally, analysis of stream length across the Basin using the GLHD Arc Hydro derived stream network could be problematic since the GLHD stream network has more meanders and detail on the Canadian side of the Basin, though the stream extents are similar across the Basin.

\section{CONCLUSION}

We used comparable data sources and consistent methods to develop spatially equivalent nested stream networks, reach catchments, and watershed boundary layers for the binational extent of the Great Lakes Basin to create the GLHD. The GLHD watersheds improve upon existing watershed efforts by delineating watersheds for the entire Basin using consistent methods; enhancing the precision of watershed delineation using recently developed flow direction grids that have been hydrologically enforced and vetted by provincial and federal water resource agencies; and increasing the accuracy of watershed boundaries by enforcing embayments, delineating watersheds on islands, and delineating watersheds for all tributaries draining to connecting channels. In addition, the GLHD is packaged in a publically available geodatabase that includes detailed metadata.

The GLHD provides a common set of spatially comparable watersheds and associated hydrography data for the entire Basin. Linking the GLHD with crosswalked U.S. and Canadian landscape datasets, such as those created by GLAHF (Wang et al., 2015), will facilitate the development of more consistent watershed-based hydrologic, loading, and assessment models at the Basin scale. As an example, the 2017 State of the Lakes Ecosystem Conference used the GLHD and GLAHF landscape data to develop a uniform summary of their land cover indicator for all watersheds in the Basin (Terry Brown, University of Minnesota Duluth, 29 October, 2015, personal communication). Consistent Basin wide analyses such as these provide critical information to managers and policy makers and are essential for developing binational strategies to protect and restore the Great Lakes.

APPENDIX 1. Agency Representation in the GLHD Technical Advisory Committee

\begin{tabular}{|c|c|}
\hline Agency Name & Division/Office \\
\hline $\begin{array}{l}\text { Michigan Department of } \\
\text { Natural Resources }\end{array}$ & $\begin{array}{l}\text { Institute for Fisheries Research, } \\
\text { Fisheries Division }\end{array}$ \\
\hline University of Michigan & $\begin{array}{l}\text { School of Natural Resources } \\
\text { and Environment }\end{array}$ \\
\hline $\begin{array}{l}\text { Ontario Ministry of } \\
\text { Natural Resources } \\
\text { and Forestry }\end{array}$ & $\begin{array}{l}\text { Land Information Ontario, } \\
\text { Water Resources Information } \\
\text { Program }\end{array}$ \\
\hline $\begin{array}{l}\text { U.S. Environmental } \\
\text { Protection Agency }\end{array}$ & Mid-Continent Ecology Division \\
\hline U.S. Geological Survey & $\begin{array}{l}\text { New England Water Science } \\
\text { Center, Great Lakes Science } \\
\text { Center }\end{array}$ \\
\hline $\begin{array}{l}\text { Agriculture and } \\
\text { Agri-Food Canada }\end{array}$ & $\begin{array}{l}\text { Agriculture Environment } \\
\text { Services Branch }\end{array}$ \\
\hline U.S. Fish and Wildlife Service & $\begin{array}{l}\text { Lower Great Lakes Fish } \\
\text { and Wildlife Conservation } \\
\text { Office }\end{array}$ \\
\hline The Nature Conservancy & $\begin{array}{l}\text { The Nature Conservancy } \\
\text { of Michigan }\end{array}$ \\
\hline Michigan State University & $\begin{array}{l}\text { Department of Fisheries } \\
\text { and Wildlife }\end{array}$ \\
\hline International Joint Commission & Great Lakes Office \\
\hline
\end{tabular}


Forsyth, Riseng, Wehrly, Mason, Gaiot, Hollenhorst, Johnston, Wyrzykowski, Annis, Castiglione, Todd, Robertson, Infante, Wang, McKenna, and Whelan

APPENDIX 2. Attributes Associated with the GLHD Watersheds and Watershed Outlet Points.

Attributes sources include the Geographic Named Extent layer (GEL); National Hydrography Dataset (NHD); National Hydrography Dataset Plus v2 (NHDPlus v2); National Hydro Network (NHN); Ontario Integrated Hydrology v1.0 (OIHDv1.0) and additions from Arc Hydro Tools or the GLHD team.

\begin{tabular}{|c|c|c|c|}
\hline Name of Field & Description & $\begin{array}{c}\text { Data } \\
\text { Source }\end{array}$ & $\begin{array}{l}\text { Field } \\
\text { Format }\end{array}$ \\
\hline HydroID & $\begin{array}{l}\text { Unique identifier created using the "Assign HydroID" tool in Arc } \\
\text { Hydro }\end{array}$ & Arc Hydro & Long \\
\hline W_Link & $\begin{array}{l}\text { An ID that links each watershed feature in } \\
\text { Watersehd_Interfluve_Altered_Attributed_Island or } \\
\text { Watershed_Interfluve_Altered_Attributed_Mainland to corresponding } \\
\text { watershed outlet points in Watershed_Altered_Attributed_Island or } \\
\text { WatershedPoint_Altered_Attributed_Mainland. The number was } \\
\text { originally derived in Arc Hydro and was combined with the OrigUnit } \\
\text { abbreviation along with an "I" for island features or an "M" for } \\
\text { mainland features }\end{array}$ & Arc Hydro/GLHD & String \\
\hline COMID & NHDPlus v2 identifier & NHDPlus v2 & Long \\
\hline $\begin{array}{l}\text { FDate_NHDPlus OR } \\
\text { FDate }\end{array}$ & $\begin{array}{l}\text { Currency date for feature. (In the Island feature class, this field is } \\
\text { called FDate_NHDPlus, in the Mainland feature class, this field is } \\
\text { called FDate) }\end{array}$ & NHDPlus v2 & Date \\
\hline RESOLUTION & Text description of dataset resolution & NHDPlus v2 & String \\
\hline GNIS_ID & GNIS ID that corresponds to GNIS_Name & NHDPlus v2 & String \\
\hline GNIS_NAME & GNIS name & NHDPlus v2 & String \\
\hline REACHCODE & Code assigned to each reach & NHDPlus v2 & String \\
\hline FLOWDIR & $\begin{array}{l}\text { Used to indicate whether the feature included in the NHDPlus v2 } \\
\text { DEM; "With Digitized" = included and "Uninitialized" = not included }\end{array}$ & NHDPlus v2 & String \\
\hline WBAREACOMI & $\begin{array}{l}\text { If the NHDPlus v } 2 \text { reach is an artificial path that flows through a } \\
\text { polygon water feature, this is the associated ComID of the polygon } \\
\text { water feature }\end{array}$ & NHDPlus v2 & Long \\
\hline FTYPE & Corresponds to the NHD Feature Type & NHDPlus v2 & String \\
\hline FCODE & Code from NHD describing type of flow line; corresponds to FTYPE & NHDPlus v2 & Long \\
\hline ENABLED & Is "True" for both OIHDv1.0 and NHDPlus v2 derived data & $\begin{array}{l}\text { NHDPlus v2, } \\
\text { OIHDv1.0 }\end{array}$ & String \\
\hline GNIS_NBR & GNIS number & NHDPlus v2 & Long \\
\hline Tertiary & Corresponding three-digit Canadian tertiary watershed code & OIHDv1.0 & String \\
\hline WRCS_TYPE & Watercourse type (default is Stream) & OIHDv1.0 & String \\
\hline PERMANENCY & Permanency of water feature & OIHDv1.0 & String \\
\hline FLOW_CLASS & $\begin{array}{l}\text { Describes the route of water flow. Two codes: Primary (main route) or } \\
\text { secondary (alternate routes such as braided streams) }\end{array}$ & OIHDv1.0 & String \\
\hline STRAHLER & Strahler stream order & OIHDv1.0 & Long \\
\hline SHREVE & Shreve stream order & OIHDv1.0 & Long \\
\hline CAN_Name & $\begin{array}{l}\text { Names attributed from the nearest downstream-reach in the NHN or } \\
\text { the GEL layer within } 200 \mathrm{~m} \text { (names are not included in the } \\
\text { OIHDv1.0 drainage network) }\end{array}$ & NHN, GEL & String \\
\hline Permanent_Identifier & NHD unique identifier & NHD & String \\
\hline FDate_NHD & $\begin{array}{l}\text { Date assorted with each feature that represents the date the feature } \\
\text { was last modified }\end{array}$ & NHD & Date \\
\hline Resolution_1 & Resolution of the feature source & NHD & Long \\
\hline GNIS_ID_1 & Unique identifier from GNIS & NHD & String \\
\hline GNIS_Name_1 & GNIS name & NHD & String \\
\hline ReachCode_1 & Unique identifier for reach & NHD & String \\
\hline FlowDir_1 & Direction of flow & NHD & Long \\
\hline $\begin{array}{l}\text { WBD_Permanent_ } \\
\text { Identifier }\end{array}$ & WBD unique identifier & NHD & String \\
\hline FType_1 & A three-digit code which represents a specific feature type & NHD & Long \\
\hline FCode_1 & $\begin{array}{l}\text { A five-digit code which is created using the feature type and other } \\
\text { characteristics }\end{array}$ & NHD & Long \\
\hline Enabled_1 & $\begin{array}{l}\text { This value is always true, and means that the feature was } \\
\text { incorporated into the geometric network }\end{array}$ & NHD & Short \\
\hline OrigUnit & $\begin{array}{l}\text { Two-digit code that corresponds to the original NHDPlus v2 } \\
\text { (4A, 4B, 4C, 4D), OIHDv1.0 (NC, NE, SW, SE), or island (LE, LH, } \\
\text { LM, LO, LS) processing unit of the flow direction grid used to } \\
\text { delineate the layer }\end{array}$ & $\begin{array}{l}\text { NHDPlus v2, OIHDv1.0, } \\
\text { NHD, GLHD }\end{array}$ & String \\
\hline
\end{tabular}




\begin{tabular}{|c|c|c|c|}
\hline Name of Field & Description & $\begin{array}{c}\text { Data } \\
\text { Source }\end{array}$ & $\begin{array}{l}\text { Field } \\
\text { Format }\end{array}$ \\
\hline Lake & $\begin{array}{l}\text { Abbreviated name of Lake basin in which the feature resides (Erie, } \\
\text { Huron, Michigan, Ontario, or Superior) }\end{array}$ & GLHD & String \\
\hline Main_Island & $\begin{array}{l}\text { Describes whether the feature is part of the mainland (Mainland) or } \\
\text { islands (Island) }\end{array}$ & GLHD & String \\
\hline Type & Original name of layer assigned by Arc Hydro & Arc Hydro, GLHD & String \\
\hline Country & $\begin{array}{l}\text { Name of the country that contains the feature (Binational, Canada, } \\
\text { U.S.). If the feature is located within both the U.S. and Canada, this } \\
\text { field is populated with "Binational" }\end{array}$ & GLHD & String \\
\hline GLHDID & $\begin{array}{l}\text { Unique ID created by the GLHD team that numbers all of the } \\
\text { watersheds and interfluves sequentially counterclockwise across the } \\
\text { Basin, beginning with the mainland Boundary Waters area. Island } \\
\text { numbers start at } 10,000 \text { and are also numbered sequentially } \\
\text { counterclockwise across the Basin }\end{array}$ & GLHD & Long \\
\hline Interfluve & $\begin{array}{l}\text { Identifies the features as either a watershed feature (blank) or an } \\
\text { interfluve feature ("Interfluve") }\end{array}$ & GLHD & String \\
\hline ShreveDL & $\begin{array}{l}\text { Shreve stream order of the most downstream-reach within } 100 \mathrm{~m} \text { of } \\
\text { an outlet point of the network created using the Stream Order tool } \\
\text { (This network was roughly equivalent to the network in the } \\
\text { DrainageLine feature class in the Synthetic_Intermediate_Layers } \\
\text { feature dataset) }\end{array}$ & $\begin{array}{l}\text { GLHD/Stream Order } \\
\text { Tool (ArcGIS Spatial } \\
\text { Analyst) }\end{array}$ & Short \\
\hline StrahlerDL & $\begin{array}{l}\text { Strahler stream order of the most downstream-reach within } 100 \mathrm{~m} \text { of } \\
\text { an outlet point of the network created using the Stream Order tool } \\
\text { (This network was roughly equivalent to the network in the } \\
\text { DrainageLine feature class in the Synthetic_Intermediate_Layers } \\
\text { feature dataset) }\end{array}$ & $\begin{array}{l}\text { GLHD/Stream Order } \\
\text { Tool (ArcGIS Spatial } \\
\text { Analyst) }\end{array}$ & Short \\
\hline
\end{tabular}

Note: DEM, Digital Elevation Model; GNIS, Geographic Names Information System; WBD, Watershed Boundary Dataset.

APPENDIX 3. Land Cover Crosswalk Categories. Data sources were the 2011 National Land Cover Database (NLCD), the 2012 Southern Ontario Land Resource Information System (SOLRIS) v2 and the 2000 Provincial Land cover Ontario (PLO).

\begin{tabular}{|c|c|c|c|}
\hline $\begin{array}{l}\text { GLAHF Common } \\
\text { Description }\end{array}$ & $\begin{array}{l}\text { NLCD } 2011 \\
\text { Description }\end{array}$ & PLO & $\begin{array}{l}\text { SOLRIS v2 } \\
\text { Description }\end{array}$ \\
\hline Great Lakes & Open Water (Great Lakes) & $\begin{array}{l}\text { Water - deep or clear, } \\
\text { Water - shallow or sedimented }\end{array}$ & Open Water \\
\hline Water & Open Water & $\begin{array}{l}\text { Water - deep or clear, } \\
\text { Water - shallow or sedimented }\end{array}$ & Open Water \\
\hline Developed & $\begin{array}{l}\text { Developed Open Space, Developed } \\
\text { Low Intensity, Developed Medium } \\
\text { Intensity, Developed High Intensity }\end{array}$ & Settlement/Infrastructure & $\begin{array}{l}\text { Transportation, Built Up Area - } \\
\text { Pervious, Built Up Area - Impervious }\end{array}$ \\
\hline Barren Land & Barren Land (Rock/Sand/Clay) & Sand/Gravel/Mine Tailings, Bedrock & $\begin{array}{l}\text { Open Beach/Bar, Open Sand Dune, } \\
\text { Open Cliff and Talus, Extraction - } \\
\text { Aggregate, Extraction - Peat/Topsoil }\end{array}$ \\
\hline Deciduous Forest & Deciduous Forest & Deciduous Forest & Deciduous Forest \\
\hline Evergreen Forest & Evergreen Forest & Coniferous Forest & Coniferous Forest \\
\hline Mixed Forest & Mixed Forest & Sparse Forest, Mixed Forest & $\begin{array}{l}\text { Treed Sand Dune, Treed Cliff and } \\
\text { Talus, Forest, Mixed Forest, } \\
\text { Hedge Row }\end{array}$ \\
\hline Scrub/Shrub & Shrub/Scrub & Regenerating depletion & Tallgrass Woodland \\
\hline $\begin{array}{l}\text { Grassland/ } \\
\text { Herbaceous }\end{array}$ & Grassland/Herbaceous & Cutovers, Burns & $\begin{array}{l}\text { Open Alvar, Shrub Alvar, Treed Alvar, } \\
\text { Open Tallgrass Prairie, Tallgrass } \\
\text { Savanah }\end{array}$ \\
\hline
\end{tabular}


Forsyth, Riseng, Wehrly, Mason, Gaiot, Hollenhorst, Johnston, Wyrzykowski, Annis, Castiglione, Todd, Robertson, Infante, Wang, McKenna, and Whelan

APPENDIX 3. Continued.

\begin{tabular}{|c|c|c|c|}
\hline $\begin{array}{l}\text { GLAHF Common } \\
\text { Description }\end{array}$ & $\begin{array}{l}\text { NLCD } 2011 \\
\text { Description }\end{array}$ & PLO & $\begin{array}{l}\text { SOLRIS v2 } \\
\text { Description }\end{array}$ \\
\hline Agriculture & Pasture/Hay, Cultivated Crops & Pasture, Cropland & $\begin{array}{l}\text { Plantations (Tree Cultivated), Tilled, } \\
\text { Undifferentiated }\end{array}$ \\
\hline Forested Wetland & Woody Wetlands & $\begin{array}{l}\text { Deciduous Swamp, Coniferous Swamp, } \\
\text { Open Fen, Treed Fen, Open Bog, } \\
\text { Treed Bog, Tundra Heath }\end{array}$ & $\begin{array}{l}\text { Treed Swamp, Thicket Swamp, } \\
\text { Fen, Bog }\end{array}$ \\
\hline Emergent Wetland & Emergent Herbaceous Wetlands & $\begin{array}{l}\text { Mud Flats, Intertidal Marsh, } \\
\text { Supertidal Marsh, Inland Marsh }\end{array}$ & Marsh \\
\hline Other/Undefined & No Data & Other (Undefined), Cloud or Shadow & N/A \\
\hline
\end{tabular}

Note: GLAHF, Great Lakes Aquatic Habitat Framework. 


\section{SUPPORTING INFORMATION}

Additional supporting information may be found online under the Supporting Information tab for this article: Table summarizing watershed area and landscape variables (roads, land cover, and population) across the GLHD watersheds.

\section{ACKNOWLEDGMENTS}

We thank Arthur Cooper for his advice and guidance on catchment and watershed development in the GIS environment. This project was funded by the Great Lakes Fishery Trust and received inkind support from the Michigan Department of Natural Resources, Ontario Ministry of Natural Resources and Forestry, International Joint Commission, National Oceanic and Atmospheric Administration Great Lakes Environmental Research Laboratory, U.S. Geological Survey, U.S. Fish and Wildlife Services, U.S. Environmental Protection Agency, Environment Canada, The Nature Conservancy, the Great Lakes Fishery Commission, University of Michigan, Michigan State University, University of Minnesota-Duluth, and University of Windsor.

\section{LITERATURE CITED}

Allan, J.D., P.B. McIntyre, S.D. Smith, B.S. Halpern, G.L. Boyer, A. Buchsbaum, G.A. Burton, L.M. Campbell, W.L. Chadderton, J.J.H. Ciborowski, P.J. Doran, T. Eder, D.M. Infante, L.B. Johnson, C.A. Joseph, A.L. Marino, A. Prusevich, J.G. Read, J.B. Rose, E.S. Rutherford, S.P. Sowa, and A.D. Steinman, 2013. Joint Analysis of Stressors and Ecosystem Services to Enhance Restoration Effectiveness. Proceedings of the National Academy of Sciences 110(1):372-377, DOI: 10.1073/pnas.1213841110.

Brakebill, J., D. Wolock, and S. Terziotti, 2011. Digital Hydrologic Networks Supporting Applications Related to Spatially Referenced Regression Modeling. Journal of the American Water Resources Association 47(5):916-932, DOI: 10.1111/j.17521688.2011.00578.x.

Danz, N.P., G.J. Niemi, R.R. Regal, T. Hollenhorst, L.B. Johnson, J.M. Hanowski, R.P. Axler, J.J. Ciborowski, T. Hrabik, V.J. Brady, J.R. Kelly, J.A. Morrice, J.C. Brazner, R.W. Howe, C.A. Johnson, and G.E. Host, 2007. Integrated Measures of Anthropogenic Stress in the U.S. Great Lakes Basin. Environmental Management 39(5):631-647, DOI: 10.1007/s00267-005-0293-0.

Environment Canada and the U.S. Environmental Protection Agency, 2014. State of the Great Lakes 2011. Cat No. En161-31/ 1-2011EPDF. EPA 950-R-13-002. http://binational.net/wp-content/ uploads/2014/11/sogl-2011-technical-report-en.pdf, accessed December 2015.

Esri, 2011. ArcGIS Desktop: Release 10. Esri, Redlands, California.

Gilliam, J.W., D.L. Osmond, and R.O. Evans, 1997. Selected Agricultural Best Management Practices to Control Nitrogen in the Neuse River Basin. NC Agricultural Research Service, North Carolina State University, Raleigh, North Carolina.

Great Lakes Water Quality Agreement, 2012. Great Lakes Water Quality Agreement, Protocol Amending the Agreement Between Canada and the United States of America on Great Lakes Water Quality, 1978, as Amended on October 16, 1983, and on November 18, 1987. Signed September 7, 2012 and entered into force February 12, 2013.
Greene, C.M., K. Blackhart, J. Nohner, A. Candelmo, and D.M. Nelson, 2014. A National Assessment of Stressors to Estuarine Fish Habitats in the Contiguous USA. Estuaries and Coasts 38(3):782799, DOI: 10.1007/s12237-014-9855-9.

Hollenhorst, T.P., T.N. Brown, L.B. Johnson, J.J. Ciborowski, and G.E. Host, 2007. Methods for Generating Multi-Scale Watershed Delineations for Indicator Development in Great Lake Coastal Ecosystems. Journal of Great Lakes Research 33:13-26, DOI: 10.3394/0380-1330(2007) 33[13:MFGMWD]2.0.CO;2.

Howell, E., K. Chomicki, and G. Kaltenecker, 2012. Tributary Discharge, Lake Circulation and Lake Biology as Drivers of Water Quality in the Canadian Nearshore of Lake Ontario. Journal of Great Lakes Research 38:47-61, DOI: 10.1016/ j.jglr.2012.03.008.

IJC (International Joint Commission), 2009. The International Watersheds Initiative: Implementing a New Paradigm for Transboundary Basins. Third Report to Governments on the International Watersheds Initiative. Cat. No.: E95-2/8-2009E, ISBN: 978-1-100- 12002-7, http://www.ijc.org/files/publications/ID1627.pdf, accessed December 2015.

Johengen, T.H., B.A. Biddanda, and J.B. Cotner, 2008. Stimulation of Lake Michigan Plankton Metabolism by Sediment Resuspension and River Runoff. Journal of Great Lakes Research 34 (2):213-227, DOI: 10.3394/0380-1330(2008) 34[213:SOLMPM] 2.0.CO;2.

Johnston, C.M., T.G. Dewald, T.R. Bondelid, B.B. Worstell, L.D. McKay, A. Rea, B.B. Moore, and J.L. Goodall, 2009. Evaluation of Catchment Delineation Methods for the Medium-Resolution National Hydrography Dataset. U.S. Geological Survey Scientific Investigations Report 2009-5233. http://pubs.usgs.gov/sir/2009/ 5233/pdf/sir2009-5233.pdf, accessed December 2015.

Kelly, J. and P. Yurista, 2013. Development of an Integrated Assessment of Large Lakes Using Towed In Situ Sensor Technologies: Linking Nearshore Conditions with Adjacent Watersheds. Aquatic Ecosystem Health \& Management 16(3):248-266.

Laitta, M., 2010. Canada-US Transboundary Hydrographic Data Harmonization Efforts Gain Momentum. Unpublished report for the International Joint Commission. http://www.ijc.org/rel/boards/ watershed/Canada-US_Hydro_Harmonization_e.pdf, accessed December 2015.

Lehner, B., 2006. HydroSHEDS Technical Documentation, version 1.2. http://www.hydrosheds.org/images/inpages/HydroSHEDS_TechDoc_v1_2.pdf, accessed December 2015.

Maidment, D. (Editor), 2002. Arc Hydro: GIS for Water Resources. Esri Press, Redlands, California, ISBN: 978-1589480346.

McKay, L., T. Bondelid, T. Dewald, J. Johnston, R. Moore, and A. Rea, 2012. NHDPlus Version 2: User Guide. ftp://ftp.horizonsystems.com/nhdplus/nhdplusv21/documentation/nhdplusv2_user_ guide.pdf, accessed December 2015.

Merwade, V., 2012. Watershed and Stream Network Delineation Using Arc Hydro Tools. https://web.ics.purdue.edu/ vmerwade/ education/terrain_processing.pdf, accessed December 2015.

Michalak, A.M., E.J. Anderson, D. Beletsky, S. Boland, N.S. Bosch, T.B. Bridgeman, J.D. Chaffin, K. Cho, R. Confesor, I. Daloğlu, J.V. DePinto, M.A. Evans, G.L. Fahnenstier, L. He, J.C. Ho, L. Jenkins, T.H. Johengen, K.C. Kuo, E. LaPorte, X. Liu, M.R. McWilliams, M.R. Moore, D.J. Posselt, R.P. Richards, D. Scavia, A.L. Steiner, E. Verhamme, D.M. Wright, and M.A. Zagorski, 2013. Record-Setting Algal Bloom in Lake Erie Caused by Agricultural and Meteorological Trends Consistent with Expected Future Conditions. Proceedings of the National Academy of Sciences, 110(16):6448-6452.

NOAA (National Oceanic and Atmospheric Administration), 2015. National Estuarine Research Reserve System, Lake Superior National Estuarine Research Reserve. Accessed September 1, 2015, http://nerrs.noaa.gov/reserves/lake-superior.html, accessed December 2015. 
OMNR (Ontario Ministry of Natural Resources), 2002. A Guide to the Provincial Watershed Project. Water Resources Information Project. Provincial Geomatics Service Center, Peterborough, Ontario. http://www.mnr.gov.on.ca/en/Business/LIO/index.html, accessed December 2015.

OMNR (Ontario Ministry of Natural Resources), 2012. Ontario Integrated Hydrology Data: Technical Specifications, Version 1.0. Water Resources Information Project, Geographic Information Branch, Science and Information Resources Division, Peterborough, Ontario, Canada.

Penskar, M.R., Y.M. Lee, M.A. Kost, D.A. Hyde, J.J. Paskus, D. L. Cuthrell, and H.D. Enander, 2002. Biological Inventory for Conservation of Great Lakes Islands: 2002 Inventory and Final Report. Michigan Department of Natural Resources Report No. 2002-27.

R Core Team, 2014. R: A Language and Environment for Statistical Computing. R Foundation for Statistical Computing, Vienna, Austria.

Riseng, C.M., M.J. Wiley, P.W. Seelbach, and R.J. Stevenson, 2010. An Ecological Assessment of Great Lakes Tributaries in the Michigan Peninsulas. Journal of Great Lakes Research 36(3):505519, DOI: 10.1016/j.jglr.2010.04.008.

Seelbach, P., J. Read, K. Buckner, T. Eder, and C. Manninen, 2014. Great Lakes Blue Accounting: Empowering Decisions to Realize Regional Water Values. A Report to the Council of Great Lakes Governors. http://glc.org/files/docs/2014-blue-accounting-recommendations-glc.pdf, accessed December 2015.

U.S. Environmental Protection Agency and Environment Canada, 2009. Nearshore Areas of the Great Lakes 2009. EPA 905-R-09013, Cat No. En164-19/2009E, http://nepis.epa.gov/Exe/ZyPURL. cgi?Dockey=9101WY1P.txt, accessed December 2015.

USACE (U.S. Army Corps of Engineers), 2009. Great Lakes Update. USACE Detroit District. vol. 175. http://www.lre.usace.army.mil/ Portals/69/docs/GreatLakesInfo/docs/UpdateArticles/Update175. pdf, accessed December 2015.

USEPA (U.S. Environmental Protection Agency), 1992. Environmental Monitoring and Assessment Program: Great Lakes Monitoring and Research Strategies. Environmental Research Laboratory, Office of Research and Development, Duluth, Minnesota. EPA/620/R-92/001.

USEPA (U.S. Environmental Protection Agency), 1996. Watershed Approach Framework. Office of Water (4501F), EPA 840-S-96001, http://water.epa.gov/learn/training/wacademy/upload/watershed-approach-framework.pdf, accessed December 2015.

U.S. Geological Survey, U.S. Department of Agriculture, U.S. Department of the Interior, and Natural Resources Conservation Service, 2013. Federal Standards and Procedures for the National Watershed Boundary Dataset (WBD) (4 ed.): Techniques and Methods 11-A3. http://pubs.usgs.gov/tm/11/a3/, accessed December 2015.

Van Rossum, G. and F. Drake, 2009. Python 2.6: Distributing Modules. CreateSpace, Paramount, California.

Wang, L., C.M. Riseng, L.A. Mason, K.E. Wehrly, E.S. Rutherford, J.E. McKenna, C. Castiglione, L.B. Johnson, D.M. Infante, S. Sowa, M. Roberston, J. Schaffer, M. Khoury, J. Gaoit, T. Hollenhorst, C. Brooks, and M. Coscarelli, 2015. A Spatial Classification and Database for Management, Research, and Policy Making: The Great Lakes Aquatic Habitat Framework. Journal of Great Lakes Research 41(2) 584:596, DOI: 10.1016/j.jglr.2015.03.017

Wehrly, K., L. Wang, D. Infante, C. Joseph, A. Cooper, L. Stanfield, and E. Rutherford, 2012. Landscape Change and Its Influence on Aquatic Habitats and Fisheries in the Great Lakes Basin. In: Great Lakes Fisheries Policy and Management: A Binational Perspective, W. Taylor, A. Lynch, and N. Leonard (Editors). Michigan State University Press, East Lansing, Michigan, pp. 81-83.

Yurista, P., J.R. Kelly, and S.E. Miller, 2011. Lake Superior: Nearshore Variability and a Landscape Driver Concept. Aquatic
Ecosystem Health \& Management 14(4):345-355, DOI: 10.1080/ 14634988.2011.624942.

Yurista, P.M., J.R. Kelly, S. Miller, and J. Van Alstine, 2012. Lake Ontario: Nearshore Conditions and Variability in Water Quality Parameters. Journal of Great Lakes Research 38:133-145, DOI: 10.1016/j.jglr.2011.09.002. 